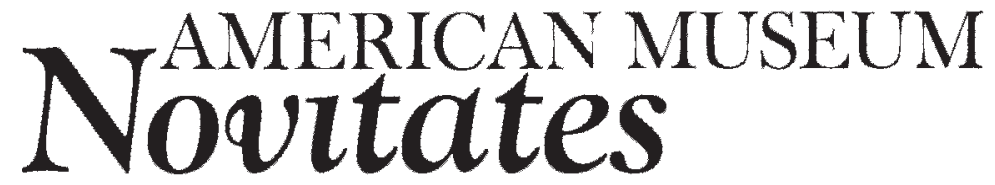

PUBLISHED BY THE AMERICAN MUSEUM OF NATURAL HISTORY CENTRAL PARK WEST AT 79TH STREET, NEW YORK, NY 10024 Number 3661, 32 pp., 8 figures, 7 tables

August 28, 2009

\title{
A New Species of the Rodent Genus Oecomys (Cricetidae: Sigmodontinae: Oryzomyini) from Eastern Bolivia, with Emended Definitions of $O$. concolor (Wagner) and O. mamorae (Thomas)
}

\author{
MICHAEL D. CARLETON, ${ }^{1}$ LOUISE H. EMMONS, ${ }^{2}$ AND GUY G. MUSSER ${ }^{3}$
}

\begin{abstract}
We describe a new species of Oecomys, O. sydandersoni (Cricetidae: Sigmodontinae), from the Parque Nacional Noel Kempff Mercado in eastern Bolivia. One of its diagnostic traits, a derived carotid circulatory plan, provides morphological evidence for its close relationship to $O$. concolor and $O$. mamorae among the 15 species of Oecomys currently recognized. Notwithstanding this shared trait, other morphological contrasts and morphometric analyses demonstrate the sharp differentiation of the eastern Bolivian form from both of those species. Oecomys sydandersoni, n. sp., is arboreal and was encountered above ground on limbs and woody vines only in densely wooded hummocks scattered through grassland, in contrast to adjacent closed tropical deciduous forest where three other species of Oecomys (O. bicolor, O. roberti, O. trinitatis) were obtained. The new species represents the fourth sigmodontine rodent to be named from this restricted region within eastern Bolivia since 1999. Its documentation served as a platform to summarize the nomenclatural history, morphological recognition, and geographic distribution of $O$. concolor (Wagner, 1845) and O. mamorae (Thomas, 1906) based on fresh examination of all type material and museum specimens.
\end{abstract}

\footnotetext{
${ }^{1}$ Division of Vertebrate Zoology (Mammalogy), American Museum of Natural History; Department of Vertebrate Zoology, National Museum of Natural History, Smithsonian Institution, Washington, DC 20560-0111 (carletonm@si. edu).

${ }^{2}$ Division of Vertebrate Zoology (Mammalogy), American Museum of Natural History; Division of Mammals, Department of Vertebrate Zoology, National Museum of Natural History, Smithsonian Institution, Washington, DC 20560-0111(emmonsl@si.edu).

${ }^{3}$ Division of Vertebrate Zoology (Mammalogy), American Museum of Natural History. Current address: 305 Clevington Way, Simpsonville, SC 29681 (holdenmusser@charter.net).
} 


\title{
RESUMEN
}

\begin{abstract}
Describimos una nueva especie de Oecomys, O. sydandersoni (Cricetidae: Sigmodontinae), colectado en el Parque Nacional Noel Kempff Mercado al este de Bolivia. Una de las características diagnósticas, el plan de circulación carotídeo derivado, provee evidencia de su relación cercana con $O$. concolor y $O$. mamorae entre las 15 especies de Oecomys reconocidas hasta la fecha. Además de esta característica compartida, otras características morfológicas y análisis morfométricos demuestran la gran differenciación de la forma del este boliviano de las otras dos especies. Oecomys sydandersoni, n. sp., es una especie arborícola y fue encontrada sobre el nivel del suelo en ramas y lianas, solamente en montecillos boscosos esparcidos por la sabana, a diferencia del bosque adyacente tropical deciduo donde las otras tres especies de Oecomys $(O$. bicolor, $O$. roberti, $O$. trinitatis) fueron encontradas. Esta nueva especie es el cuarto roedor sigmodontino descrito para esta zona del este boliviano desde 1999. Su documentación sirve como una tribuna para compendiar la historia natural, el reconocimiento morfológico, y la distribución geográfica de O. concolor (Wagner, 1845) y O. mamorae (Thomas, 1906) basados en la examinación del material tipo y de especimenes de museo.
\end{abstract}

\section{INTRODUCTION}

Arboreal rodents of the genus Oecomys (Cricetidae: Sigmodontinae) inhabit Neotropical lowland rainforests from southern Central America, throughout the broad reaches of Amazonia, to the Atlantic Forest region of southeastern Brazil (Hall, 1981; Emmons and Feer, 1997; Musser and Carleton, 2005). Described as a subgenus of Oryzomys (Thomas, 1906a), the rank of the taxon thereafter oscillated between subgenus (Goldman, 1918; Ellerman, 1941; Hershkovitz, 1960; Cabrera, 1961; Hall, 1981) and genus (Gyldenstolpe, 1932; Gardner and Patton, 1976; Carleton and Musser, 1984; Reig, 1984) until broad-scale morphological and molecular studies secured its nomenclatural stature as a monophyletic genus of Oryzomyini (Smith and Patton, 1999; Weksler, 2003, 2006). While phylogenetic appreciation of Oecomys within the oryzomyine kinship web has improved markedly, the number of valid species embraced by the taxon remains uncertain. Hershkovitz (1960) consolidated some 25 species (e.g., Gyldenstolpe, 1932; Ellerman, 1941) into just two, bicolor and concolor, an underestimation of diversity decidedly exposed by site studies in Brazil and French Guiana that have documented four species in sympatry or close parapatry (Carleton et al., 1986, as reported in Voss and Emmons, 1996: appendix 8; Patton et al., 2000; Voss et al., 2001). In a recent taxonomic compendium, Musser and
Carleton (2005) acknowledged 15 species of Oecomys but urged the need for continued faunal survey and basic taxonomic revision to enhance understanding of its specific contents.

During inventory of small mammals in eastern Bolivia, conducted over the years 1997-2006, Emmons recovered four species of Oecomys in the Parque Nacional Noel Kempff Mercado (Emmons et al., 2006), Departamento de Santa Cruz. Valid names could be reasonably assigned to three of the four morphologies-O. bicolor, O. roberti, and $O$. trinitatis-based on current taxonomic understanding, but the identity of the fourth proved to be problematic. Actually, three specimens of this indeterminate form had been earlier collected in adjacent Departamento de Beni and were reported as $O$. concolor based on certain characteristics of the pelage and cranium (Musser and Carleton, 1993, 2005; Anderson, 1997). Additional study of all material has persuaded us that Emmons' fourth form represents a new species of Oecomys that we document herein. A key diagnostic feature of the new species involves its derived carotid arterial circulatory pattern, a characteristic shared with two other Oecomys species, O. concolor (Wagner, 1845) and O. mamorae (Thomas, 1906b). Based on this potential synapomorphy (e.g., see Weksler, 2006), we critically differentiate the new species in contrast to $O$. concolor and $O$. mamorae and concurrently refine the definitions and distributions of the latter two. 


\section{Material And Methods}

Specimens examined consisted principally of prepared skins with their associated skulls housed in the following 17 natural history collections, each preceded by the institutional abbreviations adopted throughout the text, tables, and appendices. In addition, type specimens of 44 species-group taxa allocated to Oecomys (sensu Musser and Carleton, 2005) have been personally examined by at least one of us, those in North American collections by Carleton and Musser, those in European museums by Musser, and one in Brazil by Emmons. We lacked final catalog numbers for some specimens now deposited in the Instituto Nacional de Pesquisas da Amazônia, Manaus (INPA), or the Museo de Historia Natural Noel Kempff Mercado, Santa Cruz (MNK), and instead cited the insitution's abbreviation as hyphenated to the collector's initials and field number. Latitudes and longitudes used for mapping geographic ranges are provided in appendix 1, along with cartographic sources for determining those coordinates. Full provenience as given by the collector and museum catalog numbers are listed in the taxonomic accounts.

AMNH American Museum of Natural History, New York City
ANSP Academy of Natural Sciences, Philadelphia

BMNH The Natural History Museum, London (formerly British Museum of Natural History)

CAS California Academy of Sciences

CM Carnegie Museum of Natural History, Pittsburgh

FMNH Field Museum of Natural History, Chicago

INPA Instituto Nacional de Pesquisas da Amazônia, Manaus

MCZ Museum of Comparative Zoology, Harvard University, Cambridge

MN Museu Nacional da Universidade Federal do Rio de Janeiro

MNK Museo de Historia Natural Noel Kempff Mercado, Santa Cruz

MSB Museum of Southwestern Biology, University of New Mexico, Albuquerque
MSU The Museum, Michigan State University, East Lansing

MVZ Museum of Vertebrate Zoology, University of California, Berkeley

NMW Naturhistorisches Museum Wien, Wien.

UCONN University of Connecticut, Storrs

UMMZ Museum of Zoology, University of Michigan, Ann Arbor

USNM National Museum of Natural History, Smithsonian Institution, Washington D.C. (formerly U.S. National Museum)

Five external and 17 cranial dimensions (values in millimeters, $\mathrm{mm}$ ) were recorded and analyzed to quantify patterns of variation within and between population samples. External variables were generally transcribed from original skin labels as penned by collectors: total length (TOTL); length of tail vertebrae (LT); length of hind foot, including the claw (HFL); length of ear (pinna) from notch (LE); weight in grams (WT). Length of head and body (HBL) was usually calculated by subtracting the length of tail from total length. The external data are presented in tables to convey a general sense of bodily size and proportions but were not enlisted for morphometric evaluations. Crania were viewed under a dissecting microscope when measuring the 15 cranial and two dental variables to $0.1 \mathrm{~mm}$ by means of handheld digital calipers accurate to $0.03 \mathrm{~mm}$. These measurements, and their abbreviations as employed in tables, follow the landmarks defined and illustrated in past oryzomyine studies (Carleton and Musser, 1995; Musser et al., 1998): occipitonasal length (ONL); greatest zygomatic breadth (ZB); breadth of braincase at lateral extremes of lambdoidal ridge $(\mathrm{BBC})$; depth of braincase (DBC); breadth across the exoccipital condyles (BOC); least interorbital breadth (IOB); length of rostrum (LR); breadth of rostrum (BR); postpalatal length (PPL); length of bony palate (BPL); length of diastema (LD); length of incisive foramen (LIF); maximum breadth across the incisive foramina (BIF); breadth of the bony palate across the first upper molars (BBP); breadth of the zygomatic plate (BZP); 
coronal length of the maxillary toothrow (CLM); width of the first upper molar (WM1).

Relative age was coarsely indexed by degree of molar wear according to the four ageclasses (juvenile, young adult, full adult, and old adult) recognized by Carleton and Musser (1989: 4-5). Anatomical terms follow Carleton and Musser (1989), Voss and Carleton (1993), and Musser et al. (1998) for general features of the oryzomyine skull, Bugge (1970) for carotid vessels, Reig (1977) for molar cusps and enamel folds, Wahlert (1985) for cranial foramina, and Voss (1993) for the tegmen tympani; also see Weksler (2006: appendix 2) for a useful synopsis of morphological characters applied in past systematic studies of New World Muroidea.

Univariate and multivariate computations were restricted to specimens assigned to the three adult cohorts (young, full, and old). Standard descriptive parameters (mean, range, standard deviation) were derived for the species samples and are reported in table 4 for the larger samples. One-way analyses of variance, discriminant functions, and principal components were computed using only the craniodental variables, all of which were first transformed to natural logarithms. Principal components (PCs) and canonical variates (CVs) were extracted from the variance-covariance matrix, and their loadings are expressed as Pearson product-moment correlations of the derived components or variates with the original variables. Projections of individual specimen scores onto principal components, or of OTU centroids onto canonical variates, are represented as bivariate scatter plots, usually of the first two factors extracted. Similarity among the predefined geographic samples was graphically summarized using generalized Mahalanobis distances between group (OTU) centroids, and OTUs were amalgamated by the unweighted pair-group method using arithmetic averages. Type specimens were used as cases in multivariate analyses or entered as unknowns for a posteriori OTU classification based on posterior probabilities. All analytical procedures were processed using Systat for Windows (2002, version 10.2).

\section{RESULTS}

Within Muroidea, variations in the distal branching of the stapedial artery, a major subdivision of the common carotid, are especially helpful for preliminary taxonomic sorting of specimens, for these arteries leave their imprints on cleaned skulls in the presence/absence of certain cranial foramina and vascular grooves. Morphological surveys of muroid rodents over the past three decades have disclosed three principal themes of stapedial branching that appear to be generally conservative at the taxonomic levels of genus to subfamily (Bugge, 1970; Carleton, 1980; Carleton and Musser, 1984; Voss, 1988; Steppan, 1995). The tribe Oryzomyini is exceptional in that all three circulatory plans are found among its different species groups and genera (Carleton and Musser, 1989; Voss and Carleton, 1993; Musser et al., 1998; Weksler, 2006), and examples of Oecomys exhibit two of these, here simply termed "complete" and "derived."

A complete carotid circulatory pattern (character state 0 of Carleton, 1980, or pattern one per Voss, 1988) characterizes most recognized species of Oecomys. This pattern, believed to represent the ancestral state for Muroidea (Bugge, 1970; also see Weksler, 2006, for summary of recent studies), retains the supraorbital and infraorbital branches of the stapedial artery (e.g., see Carleton and Musser, 1989: fig. 21B). Osteological landmarks of the supraorbital branch include the squamosal-alisphenoid groove, where it crosses the inner surface of the squamosal and alisphenoid bones, and the sphenofrontal foramen, where it enters the orbit as the opthalmic artery. The infraorbital branch passes over the posterolateral corner of the parapterygoid fossa, typically evidenced by a shallow depression on the pterygoid bone (fig. 1), and reenters the base of the skull through the spacious posterior opening of the alisphenoid canal; it reemerges onto the orbital floor through the anterior alar fissure as the internal maxillary artery. The unreduced orbitomaxillary vessels supplied by the stapedial artery are reflected in the large, distinct stapedial foramen that straddles the petrotympanic fissure (fig. 1). We could verify this 

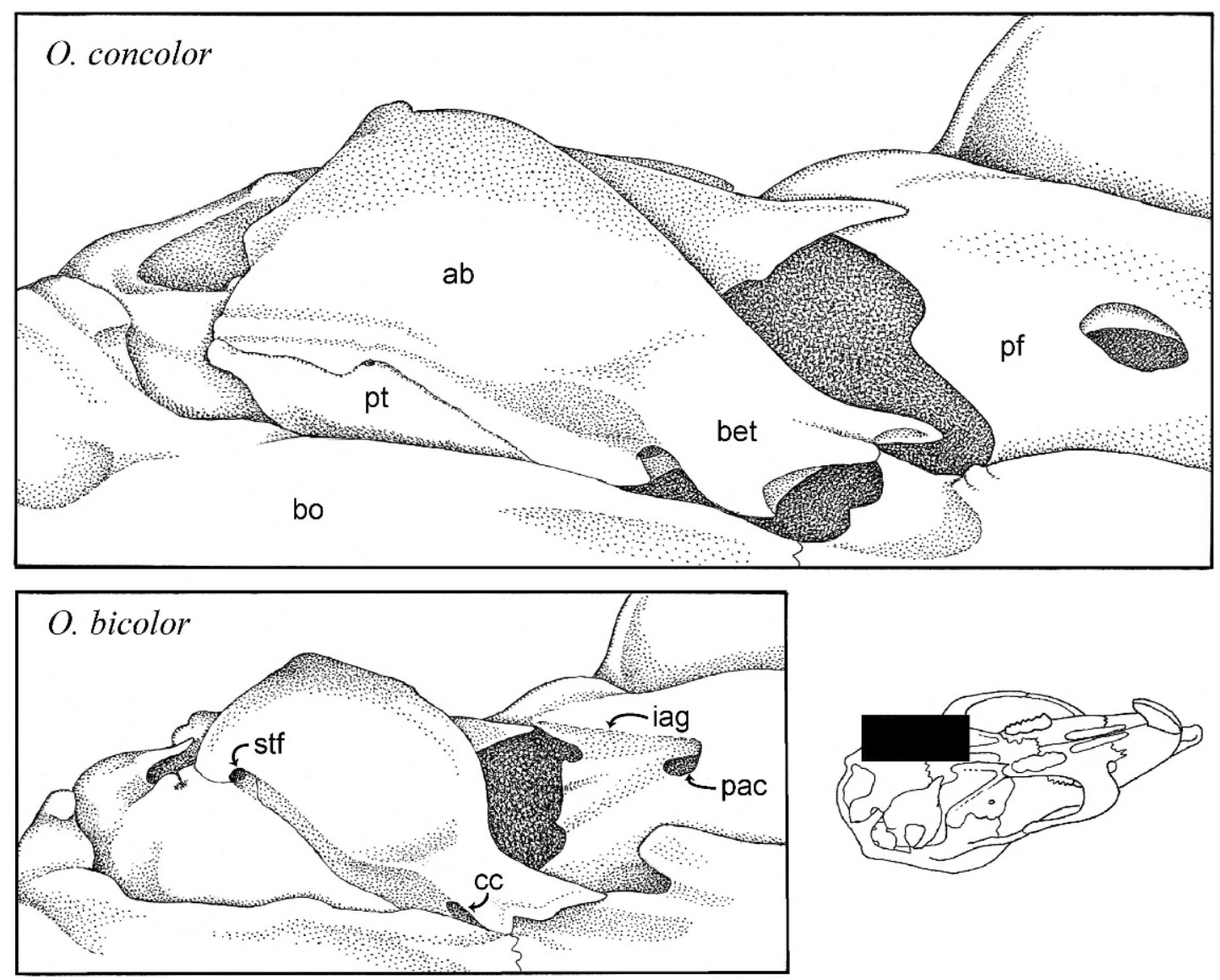

Fig. 1. Ventromedial view of right otic capsule in two species of Oecomys illustrating osseous traits associated with complete and derived carotid circulatory patterns (see text and table 1). Top, $O$. concolor (AMNH 78073, an adult from Río Casiquiare, Amazonas, Venezuela); bottom, O. bicolor (USNM 559396, an adult female from Pakitza, Madre de Dios, Peru). Abbreviations: ab, auditory bulla (ectotympanic); bet, bony eustachian tube; bo, basioccipital; cc, carotid canal; iag, groove for the infraorbital branch of the stapedial artery; pac, posterior opening to the alisphenoid canal; pf, parapterygoid fossa; pt, pteriotic (petrous portion of petro-mastoid); stf, stapedial foramen.

syndrome of cranial traits in the type specimens of 41 species-group taxa assigned to Oecomys, representing 13 currently recognized species and their 28 attributed synonyms (table 1 ).

The derived carotid circulatory plan, characteristic of far fewer members of Oecomys, involves loss of both the supraorbital and infraorbital branches of the stapedial artery and attendant cranial modifications (character state 3 of Carleton, 1980, or pattern 3 per Voss, 1988). Lack of a squamosal-alisphenoid groove and sphenofrontal foramen attests the absence of the supraorbital branch; compression or occlusion of the posterior opening to the alisphenoid canal and absence of a posterolateral groove on the parapterygoid plate accompany the loss of the infraorbital branch (fig. 1). With reduction in its distal circulation, the stapedial artery is likewise extremely reduced and the stapedial foramen, if present, is minute (fig. 1). In this condition, supply to the orbitomaxillary region is assumed by a secondary connection between the internal carotid artery and the basally conjoined opthalmic and 
TABLE 1

Character State of the Carotid Circulatory Pattern in Species-group Taxa of Oecomys

(Arranged alphabetically by valid species and chronologically by attributed synonyms.)

\begin{tabular}{|c|c|}
\hline $\begin{array}{l}\text { Species-group Taxa } \\
\text { Type Localities } \\
\text { (Holotypes) }\end{array}$ & Complete $^{\mathrm{a}}$ Derived $^{\mathrm{b}}$ \\
\hline $\begin{array}{l}\text { O. auyentepui Tate, } 1939 \\
\text { Mt. Auyan-tepui, Venezuela } \\
\text { (AMNH 131156) }\end{array}$ & + \\
\hline $\begin{array}{l}\text { O. bicolor (Tomes, } 1860 \text { ) } \\
\text { Gualaquiza, Ecuador } \\
\text { (BMNH 7.1.1.96) }\end{array}$ & + \\
\hline $\begin{array}{l}\text { dryas Thomas, } 1900 \\
\text { Paramba, Ecuador } \\
\text { (BMNH 1899.12.5.4) }\end{array}$ & + \\
\hline $\begin{array}{l}\text { benevolens Thomas, } 1901 \\
\text { Chimate, Bolivia } \\
\text { (BMNH 1.2.1.14) }\end{array}$ & + \\
\hline $\begin{array}{l}\text { rosilla Thomas, } 1904 \\
\text { La Union, Venezuela } \\
\text { (BMNH 1904.5.7.37) }\end{array}$ & + \\
\hline $\begin{array}{l}\text { nitedulus Thomas, } 1910 \\
\text { Essequibo River, Guyana } \\
\text { (BMNH 1906.4.8.31) }\end{array}$ & + \\
\hline $\begin{array}{l}\text { florenciae Allen, } 1916 \\
\text { Florencia, Colombia } \\
\text { AMNH } 33863\end{array}$ & + \\
\hline $\begin{array}{l}\text { milleri Allen, } 1916 \\
\text { Barão de Malgaço, Brazil } \\
\text { (AMNH 37117) }\end{array}$ & + \\
\hline $\begin{array}{l}\text { trabeatus Allen and Barbour, } 1923 \\
\text { Río Jesusito, Panama } \\
\text { (MCZ 19837) }\end{array}$ & + \\
\hline $\begin{array}{l}\text { endersi Goldman, } 1933 \\
\text { Barro Colorado Island, Panama } \\
\text { (UMMZ 64931) }\end{array}$ & + \\
\hline $\begin{array}{l}\text { phelpsi Tate, } 1939^{\mathrm{c}} \\
\text { Mt. Auyan-Tepui, Venezuela } \\
\text { (AMNH 131164) }\end{array}$ & + \\
\hline $\begin{array}{l}\text { occidentalis Hershkovitz, } 1960 \\
\text { Paramba, Ecuador } \\
\text { (BMNH 1899.12.5.4) }\end{array}$ & + \\
\hline $\begin{array}{l}\text { O. catherinae Thomas, } 1909 \\
\text { Joinville, Brazil } \\
\text { (BMNH 9.11.19.24) }\end{array}$ & + \\
\hline $\begin{array}{l}\text { O. cleberi Locks, } 1981 \\
\text { Fazenda Água Limpa, Brazil } \\
\text { (MN 24131) }\end{array}$ & + \\
\hline
\end{tabular}

TABLE 1

(Continued)

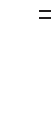

\section{$\bar{c}$}
Species-group Taxa
Type Localities
(Holotypes)

Complete $^{\mathrm{a}}$ Derived $^{\mathrm{b}}$

O. concolor (Wagner, 1845)

Mouth of Rio Curicuriare, Brazil

(NMW B482)

marmosurus Thomas, 1899

Maipures, Colombia

(BMNH 1899.9.11.38)

O. flavicans (Thomas, 1894)

Mérida, Venezuela

(BMNH 1894.9.25.14)

illectus Bangs, 1898

Pueblo Viejo, Colombia

(MCZ 8101)

mincae Allen, 1913

Minca, Colombia

(AMNH 15332)

O. mamorae (Thomas, 1906b)

Mosetenes, Bolivia

(BMNH 1900.8.3.21)

O. paricola (Thomas, 1904)

Igarapé Assu, Brazil

(BMNH 1904.7.4.63)

O. phaeotis Thomas, 1901

Sagrario, Peru

(BMNH 1901.1.1.23)

O. rex Thomas, 1910

Supenaam River, Guyana

(BMNH 1910.9.29.17)

O. roberti (Thomas, 1904)

Santa Anna da Chapada, Brazil

(BMNH 1903.7.7.67)

tapajinus Thomas, 1909

Santa Rosa, Brazil

(BMNH 1909.3.9.9)

guianae Thomas, 1910

Supenaam River, Guyana

(BMNH 1910.5.4.23)

O. rutilus Anthony, 1921

Kartabo, Guyana

(AMNH 42910)

O. speciosus (Allen

and Chapman, 1893)

Princes Town, Trinidad

(AMNH 5942/4672) 
TABLE 1

(Continued)

\begin{tabular}{|c|c|}
\hline $\begin{array}{l}\text { Species-group Taxa } \\
\text { Type Localities } \\
\text { (Holotypes) }\end{array}$ & Complete $^{\mathrm{a}}$ Derived $^{\mathrm{b}}$ \\
\hline $\begin{array}{l}\text { trichurus Allen, } 1899 \\
\text { El Libano, Colombia } \\
\text { (AMNH 15328) }\end{array}$ & + \\
\hline $\begin{array}{l}\text { caicarae Allen, } 1913 \\
\text { Caicara, Venezuela } \\
\text { (AMNH 29875) }\end{array}$ & + \\
\hline $\begin{array}{l}\text { O. superans Thomas, } 1911 \\
\text { Canelos, Ecuador } \\
\text { (BMNH 1911.7.19.12) }\end{array}$ & + \\
\hline $\begin{array}{l}\text { palmeri Thomas, } 1911 \\
\text { Canelos, Ecuador } \\
\text { (BMNH 1911.7.19.13) }\end{array}$ & + \\
\hline $\begin{array}{l}\text { melleus Anthony, } 1924 \\
\text { Zamora, Ecuador } \\
\text { (AMNH 36560) }\end{array}$ & + \\
\hline $\begin{array}{l}\text { O. trinitatis (Allen and Chapman, } \\
\text { 1893) } \\
\text { Princes Town, Trinidad } \\
\text { (AMNH 5943/4673) }\end{array}$ & + \\
\hline $\begin{array}{l}\text { subluteus Thomas, } 1898 \\
\text { Cundinamarca, Colombia } \\
\text { (BMNH 1898.7.3.2) }\end{array}$ & + \\
\hline $\begin{array}{l}\text { fulviventer Allen, } 1899 \\
\text { Quebrada Seca, Venezuela } \\
\text { (AMNH 14735) }\end{array}$ & + \\
\hline $\begin{array}{l}\text { palmarius Allen, } 1899 \\
\text { Quebrada Seca, Venezuela } \\
\text { (AMNH 14733) }\end{array}$ & + \\
\hline $\begin{array}{l}\text { tectus Thomas, } 1901 \\
\text { Bugaba, Panama } \\
\text { (BMNH 1900.7.11.43) }\end{array}$ & + \\
\hline $\begin{array}{l}\text { klagesi Allen, } 1904 \\
\text { El Yagual, Venezuela } \\
\text { (AMNH 16966) }\end{array}$ & + \\
\hline $\begin{array}{l}\text { frontalis Goldman, } 1912 \\
\text { Corazal, Panama } \\
\text { (USNM 171531) }\end{array}$ & + \\
\hline $\begin{array}{l}\text { helvolus Allen, } 1913 \\
\text { Villavicencio, Colombia } \\
\text { (AMNH 34578) }\end{array}$ & + \\
\hline $\begin{array}{l}\text { vicencianus Allen, } 1913 \\
\text { Villavicencio, Colombia } \\
\text { (AMNH 34584) }\end{array}$ & + \\
\hline
\end{tabular}

TABLE 1

(Continued)

\begin{tabular}{ll}
\hline \hline \multicolumn{1}{c}{$\begin{array}{c}\text { Species-group Taxa } \\
\text { Type Localities } \\
\text { (Holotypes) }\end{array}$} & Complete $^{\mathrm{a}}$ Derived $^{\mathrm{b}}$ \\
\hline $\begin{array}{l}\text { osgoodi } \text { Thomas, 1924 } \\
\text { Moyobamba, Peru } \\
\text { (BMNH 1924.7.11.16) }\end{array}$ & + \\
$\begin{array}{l}\text { splendens Hayman, 1938 } \\
\text { Mayaro, Trinidad } \\
\text { (BMNH 1937.11.11.2) }\end{array}$ & + \\
\hline
\end{tabular}

${ }^{\mathrm{a} C}$ Complete: supraorbital and infraorbital branches of the stapedial artery form major blood supply to the orbitofacial region; sphenofrontal and stapedial foramina present; vascular grooves cross both the inner surface of the squamosal and alisphenoid bones and the posterolateral corner of the parapterygoid fossa; posterior opening to alisphenoid canal large.

${ }^{\mathrm{b}}$ Derived: supraorbital and infraorbital branches absent, distal orbitofacial circulation arising from secondary anastomosis to the internal carotid; sphenofrontal foramen absent, stapedial foramen absent or minute; no vascular grooves found on the inner surface of the squamosal and alisphenoid bones or on the posterolateral corner of the parapterygoid fossa; posterior opening to alisphenoid canal irregularly formed or occluded; secondary osseous groove internally crosses the roof of the parapterygoid fossa.

${ }^{\mathrm{c}}$ Based on the type as restricted by Musser and Patton (1989).

internal maxillary branches. This anastomosis is suggested by a groove that diagonally crosses the parapterygoid plate, usually observed as a faint line on the translucently thin pterygoid bones, and connects medially with a very short alisphenoid canal (see Carleton and Musser, 1989: fig. 21A); exit from the braincase into the orbital fossa is through the anterior alar fissure. We observed this co-occurrence of osteological features in only three type specimens associated with Oecomys, those representing the species $O$. concolor (and its synonym marmosurus) and $O$. mamorae (table 1).

All 26 specimens of the unidentified Oecomys from eastern Bolivia possess the derived carotid circulatory pattern as just described for $O$. concolor and $O$. mamorae. Nonetheless, they differ appreciably from the latter two species in other aspects of external size, chromatic and textural characteristics of the pelage, and size and shape features of the skull. We underscore the substantial cranial 
size and shape differences among the three in the following multivariate analyses of $17 \mathrm{log}$ transformed, craniodental variables as measured on intact skulls of adult specimens. Principal component comparisons of the unidentified Oecomys are employed first with morphologically more similar $O$. concolor and then with geographically contiguous $O$. $m a-$ morae, followed by discriminant function analysis of all three species samples.

Although initially allocated to $O$. concolor, examples of the eastern Bolivian form prove to be morphometrically distinct from that species. The eastern Bolivian form possesses a generally smaller cranium, as indicated by the disposition of specimens scores on the first principal component extracted (fig. 2, top) and by the uniformly positive and strong correlation coefficients of most original variables with PC I $(r=0.53-0.96, \mathrm{P} \leq 0.001$; table 2). Shape differences are indicated by significant loadings on the second principal component, foremost those variables that reflect size of the incisive foramina (LIF, BIF; table 2). The length and width of the incisive foramina in the eastern Bolivian form are larger, both absolutely and relatively, than the foramina in specimens of $O$. concolor (table 4). Separation along PC II is also influenced by the diminutive molars (CLM, WM1) possessed by the eastern Bolivian form and its relatively short hard palate (BPL) compared with $O$. concolor (tables 2, 4). Comparable discrimination and pattern of variable loadings are apparent in the constellations of scores derived from principal component analysis of the eastern Bolivian form and geographically contiguous populations of O. mamorae (fig. 2, bottom; table 2). Size again emerges as a latent variable in the dispersion of scores along PC I (most correlations positive and large), whereas shape differences involving fewer select variables appear as important correlations on PC II. The latter once more reflect the smaller molar rows observed in the eastern Bolivian form and its wider incisive foramina compared with $O$. mamorae; also noteworthy is the absolutely wider interorbital region exhibited by the physically smaller eastern Bolivian form (tables 2, 4).

Given the only marginal contact between phenotypes apparent in the principal compo- nent analyses, scatter plots of canonical variates, extracted from discriminant function analysis of prior defined groups, predictably disclose completely nonoverlapping separation of the eastern Bolivian form from both $O$. concolor, and O. mamorae (fig. 3). Few variables account for the pronounced hiatus along CV 1. Notable are the broader interorbit (IOB) characteristic of $O$. concolor and the sample from eastern Bolivia, as well as their shorter basicranial axis (PPL), incisive foramina (LIF), and molar rows (CLM) compared with those dimensions in $\mathrm{O}$. $\mathrm{ma}$ morae (tables 3, 4). The isolation of the eastern Bolivian form on CV 2 issues from its generally smaller size relative to both $O$. concolor and $O$. mamorae and from many of the same cranial proportions divulged in the principal component comparison with $O$. concolor-spacious incisive foramina (BIF), shorter bony palate (BPL), and shorter toothrow (CLM). Mahalanobis distances between group centroids summarize these patterns of variable covariations, revealing that the eastern Bolivian form is phenetically closest to $O$. concolor and that the former two are approximately equally differentiated from $O$. mamorae.

\section{TAXONOMY}

The above morphometric evidence persuades us that Emmons' fourth form from eastern Bolivia represents a new species, perhaps closely related to $O$. concolor and $O$. mamorae as judged from their joint possession of the derived carotid circulatory pattern. This species is described next, and the taxonomic history, morphological recognition, and geographic distribution of $O$. concolor and $O$. mamorae are then summarized based on all specimens personally seen and identified by us. Synonymies presented below trace earliest identification and first subsequent usage of other genus-group and species-group name combinations.

\section{Oecomys sydandersoni, new species}

Figures 4, 5; tables 4, 6

Oecomys concolor (part): Musser and Carleton, 1993: 716; Anderson (1997: 389). 

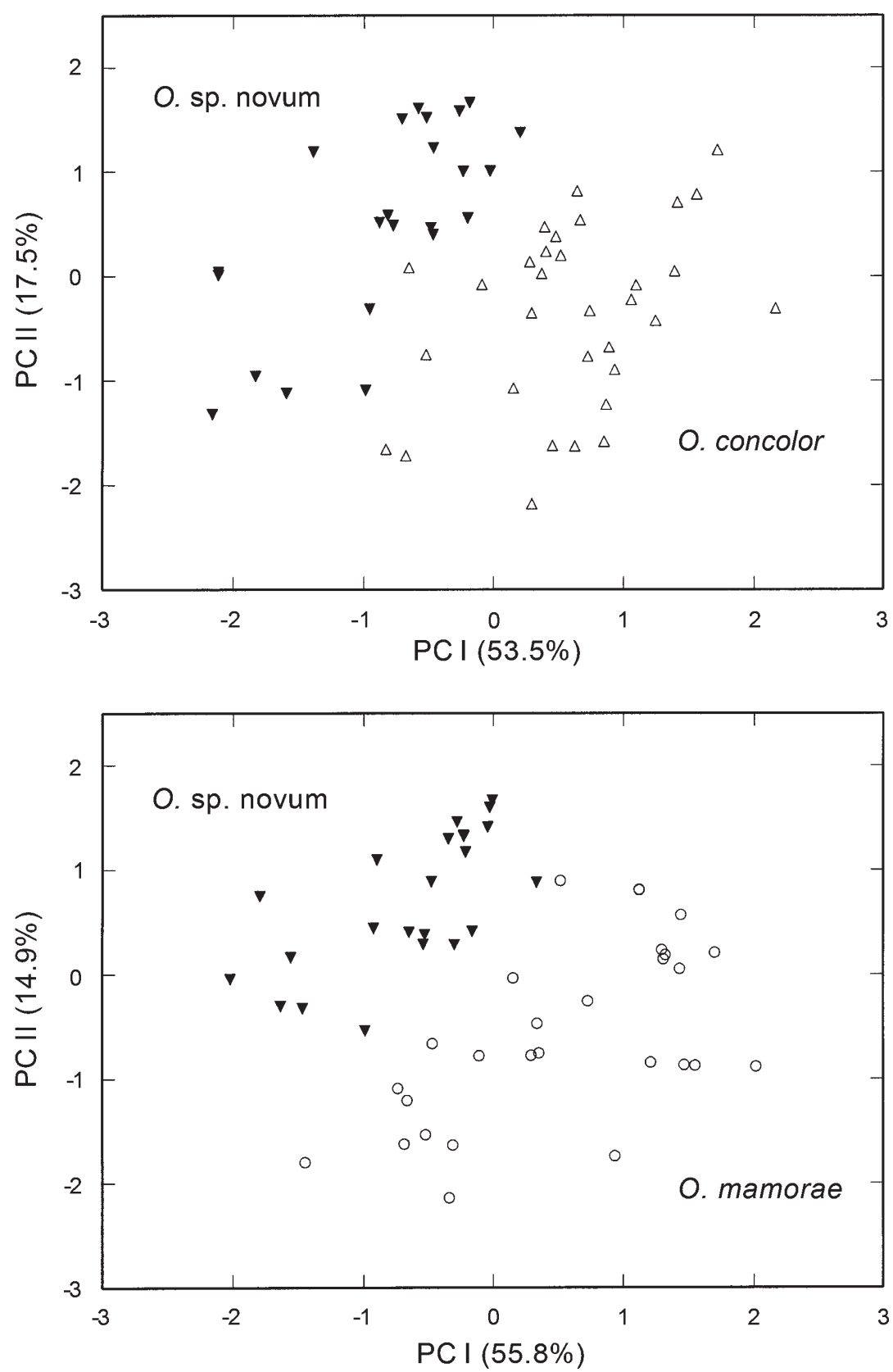

Fig. 2. Projection of specimen scores on first two factors (PC) extracted from principal component analyses comparing samples of Oecomys: top, $O$. sp. nov. $(N=22)$ and $O$. concolor $(N=32)$; bottom, $O$. $s p$. nov. $(N=22)$ and $O$. mamorae $(N=28)$. See table 2 for variable correlations and explanation of percent variance. 
TABLE 2

Results of Principal Components Analyses Comparing Adult Oecomys sp. novum with O. concolor and O. mamorae

(Based on 17 log-transformed craniodental variables; see Materials and Methods and fig. 2.)

\begin{tabular}{lccccc}
\hline \hline & \multicolumn{2}{c}{$\begin{array}{c}\text { O. sp. novum }+ \text { O. concolor } \\
\text { Correlations }\end{array}$} & & \multicolumn{2}{c}{$\begin{array}{c}\text { O. sp. novum }+ \text { O. mamorae } \\
\text { Correlations }\end{array}$} \\
\cline { 2 - 3 } \cline { 5 - 6 } Variable & PC I & PC II & & PC I & PC II \\
\hline ONL & $0.96^{* * *}$ & 0.10 & & $0.97^{* * *}$ & -0.07 \\
ZB & $0.86^{* * *}$ & 0.13 & & $0.83^{* * *}$ & 0.29 \\
BBC & $0.80^{* * *}$ & 0.02 & & $0.74^{* * *}$ & -0.15 \\
DBC & $0.53^{* * *}$ & 0.15 & & 0.32 & 0.26 \\
BOC & $0.63^{* * *}$ & -0.24 & & $0.75^{* * *}$ & -0.28 \\
IOB & $0.54^{* * *}$ & 0.13 & & -0.17 & $0.76^{* * *}$ \\
LR & $0.82^{* * *}$ & 0.26 & & $0.84^{* * *}$ & -0.05 \\
BR & $0.84^{* * *}$ & -0.04 & & $0.74^{* * *}$ & 0.06 \\
BZP & $0.76^{* * *}$ & 0.11 & & $0.88^{* * *}$ & -0.03 \\
PPL & $0.73^{* * *}$ & $0.41^{* * *}$ & & $0.91^{* * *}$ & -0.06 \\
BPL & $0.87^{* * *}$ & $-0.29^{*}$ & & $0.71^{* * *}$ & -0.14 \\
LD & $0.84^{* * *}$ & $0.35^{* *}$ & & $0.85^{* * *}$ & $0.41^{* *}$ \\
LIF & $0.35^{* *}$ & $0.72^{* * *}$ & & $0.81^{* * *}$ & -0.09 \\
BIF & -0.18 & $0.91^{* * *}$ & & 0.36 & $0.82^{* * *}$ \\
BBP & $0.82^{* * *}$ & 0.11 & & $0.78^{* * *}$ & 0.07 \\
CLM & $0.72^{* * *}$ & $-0.40^{* *}$ & & $0.59^{* * *}$ & $-0.69^{* * * *}$ \\
WM1 & $0.64^{* * *}$ & $-0.37^{* *}$ & & 0.38 & $-0.58^{* * *}$ \\
Eigenvalue & 0.033 & 0.011 & & 0.045 & 0.012 \\
\% Variance & 53.5 & 17.5 & & 55.8 & 14.9 \\
\hline
\end{tabular}

$*=\mathrm{P} \leq 0.05 ; * *=\mathrm{P} \leq 0.01 ; * * * \mathrm{P} \leq 0.001$.

Holotype: Museo de Historia Natural Noel Kempff Mercado number 2679, an adult male prepared as round skin and skull; collected 30 July 1997 by Louise H. Emmons (original field number LHE 1415).

External data recorded on the skin tag include: TOTL, $242 \mathrm{~mm}$; TL, $124 \mathrm{~mm}$; HFL, $23 \mathrm{~mm}$; EL, $17 \mathrm{~mm}$; WT, $45 \mathrm{~g}$ (see table 4 for craniodental measurements of the type). The animal was noted as having scrotal testes (11 $\times 7 \mathrm{~mm}$ ) and was captured "in pampa brush on vines."

Type Locality: Bolivia, Departamento de Santa Cruz, Provincia Velasco, El Refugio Huanchaca, $210 \mathrm{~m}$; $14^{\circ} 46^{\prime} 01^{\prime \prime} \mathrm{S} / 61^{\circ} 02^{\prime} 02^{\prime \prime} \mathrm{W}$ (field coordinates as given by the collector; GPS, map datum WGS84).

On older maps, the locality now known as El Refugio Huanchaca appears only as Huanchaca, a biological station with a few buildings and an airstrip on private property but now partly within the park. The present owners of the estancia renamed it El Refugio, the place name that appears on specimen labels, but in 2004, they appended Huanchaca to their former designation of El Refugio. "El Refugio," "Huanchaca," and the combined form "El Refugio Huanchaca," as applied in eastern Santa Cruz, are one and the same locality.

Diagnosis: A species of Oecomys (Sigmodontinae: Oryzomyini) characterized by a combination of medium size $(\mathrm{HBL} \approx 115$ $135 \mathrm{~mm}, \mathrm{HFL} \approx 23-25 \mathrm{~mm}, \mathrm{ONL} \approx 29$ $31 \mathrm{~mm})$, relatively short tail $(\mathrm{TL} \approx 125$ $140 \mathrm{~mm}$ ), absolutely and relatively very wide incisive foramina, smaller molars (CLM $\approx$ 4.4-4.7), presence of alisphenoid struts, and a derived carotid circulatory pattern (skull lacking squamosal-alisphenoid groove, sphenofrontal foramen, and posterolateral groove on the parapterygoid plate; posterior opening to the alisphenoid canal compressed; stapedial foramen absent; groove dorsally crossing the parapterygoid plate present).

Referred Specimens: BOLIVIA: Beni, Río Iténez, ca. $4 \mathrm{~km}$ above Costa Marques, $12^{\circ} 29^{\prime} \mathrm{S} / 64^{\circ} 15^{\prime} \mathrm{W}$ (AMNH 210023); Río Ité- 


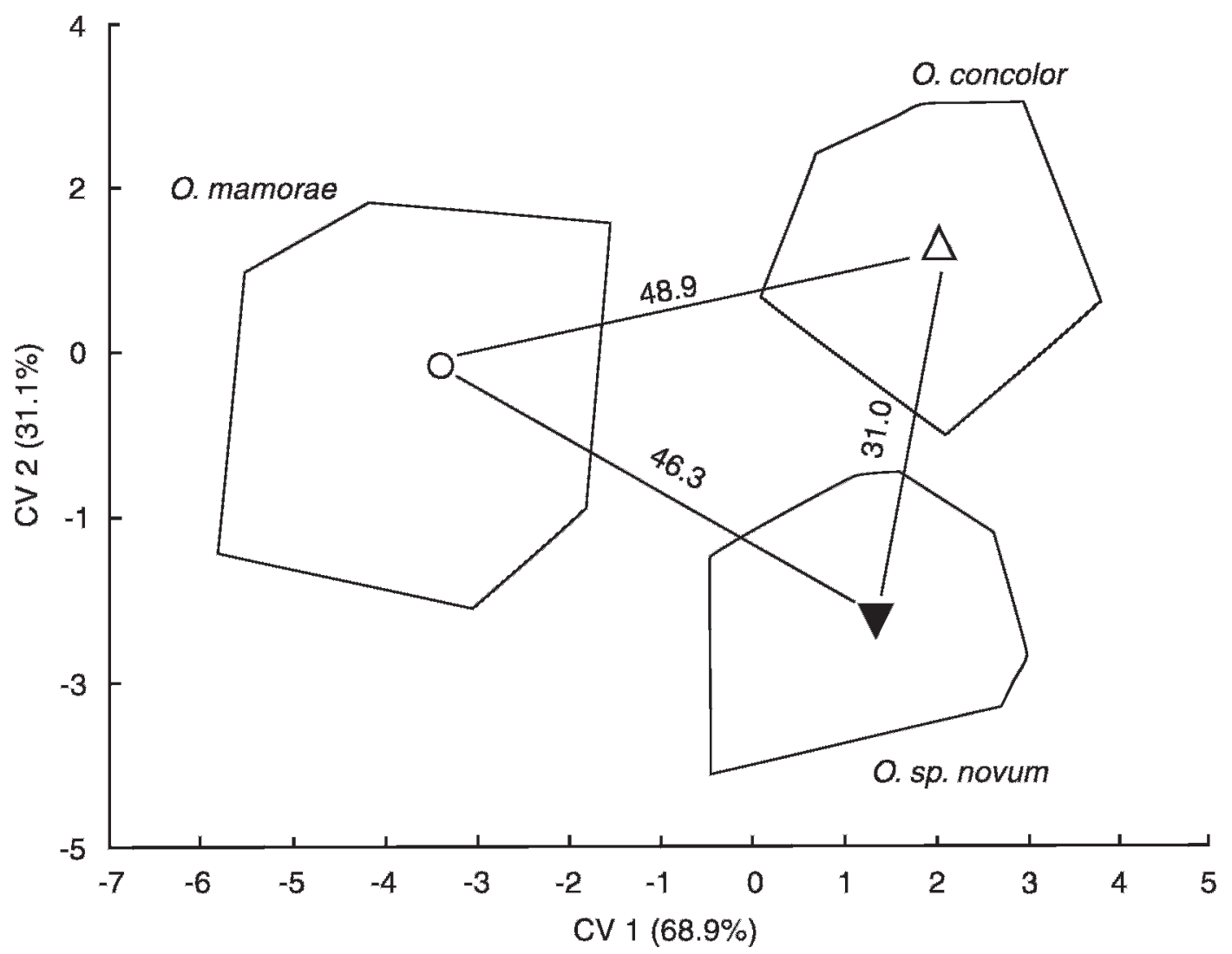

Fig. 3. Projection of specimen scores on first two canonical variates (CV) extracted from three-group discriminant function analysis of samples representing Oecomys concolor $(N=32)$, O. mamorae $(N=28)$, and $O$. sp. nov. $(N=22)$. The maximally inclusive polygons enclose specimen scores around an OTU's centroid; average divergences (Mahalanobis $\mathrm{D}^{2}$ ) among the three samples are indicated along the lines between the centroids. See table 3 for variable correlations and explanation of percent variance.

nez, bank opposite Costa Marques, $12^{\circ} 29^{\prime} \mathrm{S} /$ 64 17’W (AMNH 209987); Bahía de los Casara, $20 \mathrm{~km}$ W Larangiera, Río Iténez, $13^{\circ} 13^{\prime} \mathrm{S} / 62^{\circ} 21^{\prime} \mathrm{W}$ (AMNH 210012). Santa Cruz, El Refugio, $210 \mathrm{~m}, 14^{\circ} 46^{\prime} 01^{\prime \prime} \mathrm{S} /$ $61^{\circ} 02^{\prime} 02^{\prime \prime} \mathrm{W}$ (USNM 588189, 588190; MNKLHE 1412); $3 \mathrm{~km}$ NE El Refugio, Pampa, $14^{\circ} 44^{\prime} 35^{\prime \prime} \mathrm{S} / 61^{\circ} 01^{\prime} 20^{\prime \prime} \mathrm{W}$ (MNK 3763, 3765, 3766, 3772, 3776-3778, 3782, 3788; USNM 584554-584663.

Distribution: Extreme eastern Bolivia (fig. 6).

DesCRIPTION: Size of $O$. sydandersoni medium for the genus (e.g., larger than $O$. bicolor or $O$. auyantepui, smaller than $O$. mamorae or $O$. roberti-see fig. 4 and tables 4,6 herein; and table 28 in Voss et al. 2001). Fur texture soft and fine; pelage moderately short, hairs about 5-7 $\mathrm{mm}$ long over the middle rump. Dorsal pelage ochraceous brown to pale tawny, finely intermixed with black over the middle dorsum and generally bright in tone; more grayish showing on head and flanks. General appearance of ventral pelage a pale to medium gray; hairs of chin, throat, and around inguinum entirely white to base in most specimens; hairs over chest and abdomen gray basally with long white tips. Dorsalventral pelage transition moderately defined, without ochraceous lateral line. Eyelids black but no eye-ring per se. Pinnae dark brown to brownish gray, thinly covered with short, ochraceous hairs. Upper surfaces of metatarsals and phalanges covered with whitish to pale ochraceous hairs, general appearance of hind foot a dirty white. Hind-foot conforma- 
TABLE 3

Results of Three-group Discriminant Function Analysis of Adult Oecomys sp. novum, $O$. concolor, and $O$. mamorae

(Based on 17 log-transformed craniodental variables; see Materials and Methods and fig. 3.)

\begin{tabular}{|c|c|c|}
\hline \multirow[b]{2}{*}{ Variable } & \multicolumn{2}{|c|}{ Correlations } \\
\hline & CV 1 & CV 2 \\
\hline ONL & -0.31 & $0.66^{* * *}$ \\
\hline $\mathrm{ZB}$ & 0.08 & $0.41 * *$ \\
\hline $\mathrm{BBC}$ & -0.23 & $0.51 * * *$ \\
\hline $\mathrm{DBC}$ & 0.33 & 0.24 \\
\hline $\mathrm{BOC}$ & $-0.56^{* * *}$ & $0.50 * * *$ \\
\hline IOB & $0.75^{* * *}$ & 0.12 \\
\hline LR & -0.28 & $0.47 * * *$ \\
\hline $\mathrm{BR}$ & 0.19 & $0.61 * * *$ \\
\hline BZP & $-0.37^{*}$ & $0.35^{*}$ \\
\hline PPL & $-0.61 * * *$ & 0.26 \\
\hline BPL & 0.20 & $0.83 * * *$ \\
\hline LD & 0.03 & $0.41 * *$ \\
\hline LIF & $-0.63 * * *$ & 0.07 \\
\hline $\mathrm{BIF}$ & -0.09 & $-0.45 * * *$ \\
\hline BBP & 0.01 & $0.52 * * *$ \\
\hline CLM & $-0.47 * * *$ & $0.72 * * *$ \\
\hline WM1 & -0.09 & $0.54 * * *$ \\
\hline Canonical correlations & 0.93 & 0.86 \\
\hline Eigenvalue & 6.15 & 2.77 \\
\hline$\%$ Variance & 68.9 & 31.1 \\
\hline
\end{tabular}

$*=\mathrm{P} \leq 0.05 ; * *=\mathrm{P} \leq 0.01 ; * * *=\mathrm{P} \leq 0.001$

tion typical of the genus - relatively short and broad; bright white ungual tufts developed on digits II-V; digit V nearly as long as digits IIIV; plantar surface smooth with six large, closely positioned pads, the thenar and hypothenar well developed. Tail slightly longer than head and body; color medium to dark brown all around, slightly paler underneath at the base; caudal hairs short, scarcely visible to the unaided eye and not obscuring fine scale pattern; rudimentary pencil expressed at tip of tail.

Skull ruggedly built for its size, with short rostrum and relatively broad interorbit. Supraorbital shelves present, converging forward such that the least interorbital width is projected relatively anteriad between the orbits; free ledge over orbit heavy, approaching an incipient bead; low temporal ridging continues across the lateral parietals in older individuals. Zygomatic arches noticeably expanded at rear and strongly tapered rostrally; dorsal notch of zygomatic plate well defined, plate relatively broad. Posterolateral wall of braincase consistently perforated by small subsquamosal fenestra, shape slitlike or narrowly ovoid, about one-half the area of the postglenoid foramen; tegmen tympani reduced, touching the ventrolateral squamosal in some specimens but not overlapping it. Alisphenoid struts typically present, delineating a discrete foramen ovale accessorius and masticatory-buccinator foramen. Incisive foramina medium long but very broad, posteriorly terminating just anterior to the anterior root of the M1s; foramina widest toward the rear, posterior ends obtuse (blunt) and anterior ends acute, in some specimens the transition from wide to narrow abrupt. Hard palate basically flat, the palatal gutters shallow and barely evident to the naked eye; palate extends slightly beyond posterior margin of M3s; posterior palatine foramen exits about the middle of M2. Posterolateral-palatal pits well expressed, usually as one large pit with interior perforations plus one or two supernumerary foramina emerging immediately anterior. Mesopterygoid fossa broad and wide, its anterior margin bluntly U-shaped, lacking medial spine or blunt protrusion; roof of mesopterygoid fossa entirely osseous, not perforated by sphenopalatine vacuities. Ectotympanic bulla small, revealing much of the medial periotic, which contributes (as viewed ventrally) to the rear border of the carotid canal.

Upper incisors opisthodont, enamel colored dull yellow-orange to a moderately saturated orange. Molars brachyodont and cuspidate as per the genus, uppers with three roots and lowers with two. M1 with well-formed anteroloph and M1-2 with mesoloph. Anterocone broad, anterolingual and anterolabial conules joined medially, not cleft by anteromedian fold; conules distinct in juveniles and young adults, but definition lost with wear. Mesolophid consistently present on m1-2; ectolophid variably developed, absent in some individuals.

In one-way ANOVAs, none of the 18 craniodental variables demonstrated significant secondary sexual dimorphism (14 $\hat{\delta}$, 11 ㅇ ; $\mathrm{F}=0.025-3.391 ; \mathrm{P}=0.975-0.054)$.

Morphological Comparisons: Specimens of $O$. sydandersoni can be separated from most 
species of Oecomys based solely on the osseous character-state differences associated with the complete versus derived carotid arterial patterns (see above descriptions under Results). Other features must be consulted for discrimination from $O$. concolor and $O$. mamorae, the other species so far known to possess a derived carotid plan. We encountered slight variation in the expression of the derived carotid pattern among the entire series examined of these three species. In some individuals of $O$. mamorae (UMMZ 125456, 133793; UCONN 19187-19189) and $O$. sydandersoni (USNM 584554,584558 ), but none of $O$. concolor, a vestige of a squamosal-alisphenoid groove can be detected on the inner wall of the braincase, but no sphenofrontal foramen is present; in these cases, the stapedial foramen persists as a minute pinhole, a tiny aperture in comparison with the full foramen observed in those Oecomys with a complete carotid circulatory pattern. Notwithstanding these individual exceptions, a large majority of specimens of $O$. mamorae and $O$. sydandersoni display the typical derived condition as described under Results. Such occasional atavistic reminders of the ancestral character state are to be expected in view of the evolutionary polarity established for carotid arterial patterns in muroid rodents (Bugge, 1970; Carleton, 1980; Voss, 1988; Weksler, 2006).

As currently documented, a wide geographic gap separates the ranges of $O$. sydandersoni, in eastern Bolivia, and $O$. concolor, in southern Venezuela and northwestern Brazil (fig. 6). Examples of $O$. sydandersoni and $O$. mamorae, however, have been collected in close proximity in eastern Bolivia (fig. 6), and their identification may pose greater difficulty. Individuals of $O$. sydandersoni are smaller than those of $O$. concolor and $O$. mamorae, a contrast readily appreciated from variable loadings derived for the first principal component (fig. 2; table 2) or simple inspection of univariate means (table 4). Length of tail is absolutely and relatively shorter in specimens of O. sydandersoni (TL $\approx 106 \%$ of $\mathrm{HBL}$ ) compared with those of $O$. concolor $(\mathrm{TL} \approx$ $118 \%$ of HBL) and $O$. mamorae (TL $\approx 113 \%$ of HBL). The dorsal pelage of $O$. sydandersoni is only slightly longer $(5-7 \mathrm{~mm})$, as measured on the rump, than that possessed by the short- furred $O$. concolor $(4-5 \mathrm{~mm})$; dorsal pelage of $O$. mamorae is the longest of the three (7$9 \mathrm{~mm}$ ). Oecomys sydandersoni and $O$. concolor resemble one another in dorsal pelage coloration, albeit somewhat darker in tone in $O$. concolor. More grayish hues are evident over the head and flanks of $O$. sydandersoni, compared with a dominant fulvous-brown color in $O$. concolor. The dorsal pelage of $O$. mamorae shows the most gray, ranging from gray to grayish buff, and a buffy to bright ochraceous lateral strip demarcates the upperand underparts in most specimens. The ventrum of $O$. sydandersoni appears gray, in contrast to dull white, from the chin to inguinum, as observed in most specimens of $O$. concolor and $O$. mamorae; some individuals of the latter two exhibit encroachment of basal gray hairs over the middle abdomen. The dorsal-ventral pelage contrast thus tends to be more sharply marked in $O$. concolor and $O$. mamorae.

Besides cranial size (table 4), subtle but consistent differences in shape provide other reliable means to distinguish the three species (fig. 4). The condition of the supraorbital shelf and interorbital region is similar in $O$. sydandersoni and $O$. concolor, and both differ in the same ways from $O$. mamorae. In the latter species, the interorbit is narrower, and the free edge of the shelf is thinner, less prominent, and confined to the rear of the orbit. Hence, the least interorbital constriction of $O$. mamorae occurs about the middle of orbits (more amphoral), whereas the more prominent shelves in $O$. sydandersoni and $O$. concolor extend farther forward such that the least interorbital width appears more anteriad (more cuneate). The zygomatic plate is broadest in specimens of $O$. mamorae (table 4), and its dorsal notch appears more deeply excised compared with $O$. sydandersoni and $O$. concolor. Posterior termination of the incisive foramina is approximately the same in all three species, reaching the level of the anterior root of the first molars, but their typical shape differs notably among them: anterior and posterior ends acute in $O$. concolor, gently curving along the lateral edges and widest near their middle; foramina also widest at the middle in $O$. mamorae, but outward bowing less pronounced, the foramina appearing more 
TABLE 4

External and Craniodental Measurements for the Type Series of $O$. sydandersoni, New Species, and Samples of $O$. concolor and $O$. mamorae

(Sample statistics include the mean, \pm 1 standard deviation, and the observed range).

\begin{tabular}{|c|c|c|c|c|}
\hline Variable & $\begin{array}{l}\text { O. sydandersoni } \\
\text { Holotype } \\
\text { (MNK 2679) }\end{array}$ & $\begin{array}{l}\text { O. sydandersoni } \\
\text { El Refugio } \\
(N=21-23)\end{array}$ & $\begin{array}{c}\text { O. concolor } \\
\text { Amazonas, Brazil } \\
(N=23,24)\end{array}$ & $\begin{array}{l}\text { O. mamorae } \\
\text { Beni, Bolivia } \\
(N=14-16)\end{array}$ \\
\hline TOTL & 242 & $\begin{array}{c}257.9 \pm 16.7 \\
233-290\end{array}$ & $\begin{array}{c}273.2 \pm 11.2 \\
255-296\end{array}$ & $\begin{array}{c}296.0 \pm 18.3 \\
270-230\end{array}$ \\
\hline HBL & 118 & $\begin{array}{c}125.0 \pm 12.2 \\
109-166\end{array}$ & $\begin{array}{c}125.4 \pm 5.8 \\
115-141\end{array}$ & $\begin{array}{c}139.8 \pm 13.1 \\
120-170\end{array}$ \\
\hline TL & 124 & $\begin{array}{c}132.8 \pm 8.4 \\
115-145\end{array}$ & $\begin{array}{c}147.9 \pm 6.9 \\
137-160\end{array}$ & $\begin{array}{c}158.5 \pm 10.7 \\
144-180\end{array}$ \\
\hline HFL & 23 & $\begin{array}{c}24.1 \pm 1.7 \\
21-27\end{array}$ & $\begin{array}{c}27.4 \pm 1.1 \\
26-29\end{array}$ & $\begin{array}{c}27.3 \pm 1.8 \\
23-30\end{array}$ \\
\hline EL & 17 & $\begin{array}{c}16.4 \pm 1.1 \\
15-19\end{array}$ & $\begin{array}{c}17.1 \pm 1.3 \\
15-20\end{array}$ & $\begin{array}{c}18.0 \pm 1.2 \\
17-20\end{array}$ \\
\hline WT & 45 & $\begin{array}{c}44.9 \pm 7.8 \\
30-57\end{array}$ & $\begin{array}{c}57.8 \pm 9.5 \\
41-80\end{array}$ & $\begin{array}{c}73.9 \pm 29.9 \\
48-120\end{array}$ \\
\hline ONL & 30.7 & $\begin{array}{r}29.8 \pm 1.2 \\
27.7-32.0\end{array}$ & $\begin{array}{r}32.2 \pm 0.9 \\
30.2-34.3\end{array}$ & $\begin{array}{r}32.5 \pm 1.2 \\
30.9-34.5\end{array}$ \\
\hline $\mathrm{ZB}$ & 16.7 & $\begin{array}{r}16.5 \pm 0.6 \\
15.3-17.6\end{array}$ & $\begin{array}{r}17.7 \pm 0.6 \\
16.6-19.1\end{array}$ & $\begin{array}{r}17.1 \pm 0.7 \\
15.6-18.1\end{array}$ \\
\hline $\mathrm{BBC}$ & 11.8 & $\begin{array}{r}11.8 \pm 0.3 \\
11.3-12.4\end{array}$ & $\begin{array}{r}12.5 \pm 0.4 \\
11.8-13.3\end{array}$ & $\begin{array}{r}12.6 \pm 0.3 \\
12.0-13.2\end{array}$ \\
\hline $\mathrm{DBC}$ & 9.5 & $\begin{array}{c}9.1 \pm 0.3 \\
8.5-9.7\end{array}$ & $\begin{array}{c}9.4 \pm 0.3 \\
8.8-9.9\end{array}$ & $\begin{array}{r}9.3 \pm 0.5 \\
7.7-10.0\end{array}$ \\
\hline BOC & 6.6 & $\begin{array}{c}6.5 \pm 0.1 \\
6.3-6.8\end{array}$ & $\begin{array}{c}6.8 \pm 0.2 \\
6.4-7.3\end{array}$ & $\begin{array}{c}7.3 \pm 0.4 \\
6.6-7.8\end{array}$ \\
\hline IOB & 5.4 & $\begin{array}{c}5.3 \pm 0.3 \\
4.8-5.7\end{array}$ & $\begin{array}{c}5.5 \pm 0.2 \\
5.1-6.0\end{array}$ & $\begin{array}{c}4.9 \pm 0.2 \\
4.6-5.2\end{array}$ \\
\hline LR & 8.2 & $\begin{array}{c}8.4 \pm 0.5 \\
7.5-9.1\end{array}$ & $\begin{array}{c}9.1 \pm 0.4 \\
8.4-9.9\end{array}$ & $\begin{array}{r}9.1 \pm 0.4 \\
8.6-10.0\end{array}$ \\
\hline $\mathrm{BR}$ & 5.4 & $\begin{array}{c}5.5 \pm 0.3 \\
4.7-6.2\end{array}$ & $\begin{array}{c}6.1 \pm 0.3 \\
5.5-6.7\end{array}$ & $\begin{array}{c}5.8 \pm 0.3 \\
5.4-6.2\end{array}$ \\
\hline PPL & 10.4 & $\begin{array}{r}10.3 \pm 0.5 \\
9.2-11.4\end{array}$ & $\begin{array}{r}10.6 \pm 0.4 \\
9.9-11.4\end{array}$ & $\begin{array}{r}11.3 \pm 0.5 \\
10.4-12.0\end{array}$ \\
\hline BPL & 5.7 & $\begin{array}{c}5.6 \pm 0.3 \\
4.9-6.0\end{array}$ & $\begin{array}{c}6.6 \pm 0.3 \\
5.9-7.3\end{array}$ & $\begin{array}{c}6.1 \pm 0.4 \\
5.4-6.9\end{array}$ \\
\hline LIF & 5.6 & $\begin{array}{c}5.4 \pm 0.3 \\
4.9-5.8\end{array}$ & $\begin{array}{c}5.3 \pm 0.3 \\
4.5-6.2\end{array}$ & $\begin{array}{c}5.8 \pm 0.3 \\
5.3-6.3\end{array}$ \\
\hline BIF & 2.6 & $\begin{array}{c}2.6 \pm 0.2 \\
2.2-2.8\end{array}$ & $\begin{array}{c}2.3 \pm 0.2 \\
1.8-2.7\end{array}$ & $\begin{array}{c}2.5 \pm 0.3 \\
2.0-2.9\end{array}$ \\
\hline LD & 7.4 & $\begin{array}{c}7.7 \pm 0.5 \\
6.8-8.7\end{array}$ & $\begin{array}{c}8.1 \pm 0.4 \\
7.6-9.1\end{array}$ & $\begin{array}{c}8.0 \pm 0.5 \\
7.2-8.7\end{array}$ \\
\hline BBP & 5.7 & $\begin{array}{c}5.7 \pm 0.2 \\
5.2-6.2\end{array}$ & $\begin{array}{c}6.1 \pm 0.2 \\
5.7-6.4\end{array}$ & $\begin{array}{c}5.9 \pm 0.3 \\
5.4-6.4\end{array}$ \\
\hline
\end{tabular}


TABLE 4

(Continued)

\begin{tabular}{lcccc}
\hline \hline Variable & $\begin{array}{c}\text { O. sydandersoni } \\
\text { Holotype } \\
(\text { MNK 2679) }\end{array}$ & $\begin{array}{c}\text { O. sydandersoni } \\
\text { El Refugio } \\
(N=21-23)\end{array}$ & $\begin{array}{c}\text { O. concolor } \\
\text { Amazonas, Brazil } \\
(N=23,24)\end{array}$ & $\begin{array}{c}\text { O. mamorae } \\
\text { Beni, Bolivia } \\
(N=14-16)\end{array}$ \\
\hline BZP & 3.2 & $2.9 \pm 0.2$ & $3.3 \pm 0.2$ & $3.4 \pm 0.3$ \\
& & $2.5-3.2$ & $2.9-3.6$ & $2.8-3.9$ \\
CLM & 4.80 & $4.57 \pm 0.14$ & $4.93 \pm 0.13$ & $5.04 \pm 0.21$ \\
& & $4.35-4.90$ & $4.70-5.10$ & $4.70-5.40$ \\
WM1 & 1.40 & $1.32 \pm 0.05$ & $1.40 \pm 0.06$ & $1.39 \pm 0.09$ \\
& & $1.25-1.40$ & $1.30-1.50$ & $1.30-1.50$ \\
\hline
\end{tabular}

nearly parallel sided and narrower; the foramina in $O$. sydandersoni are noticeably widest toward the rear, the posterior ends obtuse (blunt) and anterior ends acute. The bony palate noticeably projects beyond the posterior margins of the $\mathrm{M} 3 \mathrm{~s}$ in examples of $O$. sydandersoni and $O$. concolor, as in most oryzomyines, but the rear termination of the hard palate in $O$. mamorae is more or less even with the caudal margin of the M3s. Perhaps in correlation with their longer palates, the posterolateral palatal pits are well developed in the former two-typically as one large pit with interior perforations plus one or two supernumerary foramina emerging immediately anterior-whereas pit construction in $O$. mamorae is simpler, usually consisting of a single opening. Most of these size and shape contrasts figure prominently in the phenetic patterns derived from the various multivariate analyses and are reflected in the signs and strengths of variable loadings (figs. 2, 3; tables 2, 3; see Results).

The occurrence of the alisphenoid strut, the slim bony column that delineates foramina at the base of the alisphenoid, varies within and among species of oryzomyines (Carleton and Musser, 1989; Voss and Carleton, 1993; Musser et al., 1998), including those of Oecomys (Weksler, 2006). Among the three species with a derived carotid pattern, we observed an alisphenoid strut in most specimens of $O$. concolor and $O$. sydandersoni but rarely in those of $O$. mamorae (table 5). In some individuals, the strut exists as a slender thread (which we counted as present) or is found on only one side of the skull. Used in conjunction with other measurements and qualitative traits, the presence/absence of the alisphenoid strut is useful for identifying specimens of $O$. mamorae and $O$. sydandersoni where their ranges approach one another.

Three other species of Oecomys-O. bicolor, $O$. roberti, and $O$. trinitatis-have been documented to date in the Parque Nacional Noel Kempff Mercado (Emmons et al., 2006), albeit not in syntopy with $O$. sydandersoni (see below). The three can be easily differentiated from the new species by a combination of size and qualitative features of the skin and skull. Foremost, they all possess a complete carotid circulatory plan, in contrast to the derived pattern exhibited by specimens of $O$. sydandersoni. Oecomys bicolor is a diminutive species compared with $O$. sydandersoni and averages appreciably smaller in every external and cranial dimension quantified (table 6). The dorsal pelage of $O$. bicolor is shorter and closely cropped, 3-4 $\mathrm{mm}$ long at rump (pelage longer in $O$. sydandersoni, 5-7 $\mathrm{mm}$ ), and its ventral pelage is uniformly bright white (mostly gray in $O$. sydandersoni). Furthermore, O. bicolor possesses a relatively shorter tail, only about as long as the head and body (longer, absolutely and relative to the head and body in $O$. sydandersoni), and the caudal hairs are longer, forming a more distinct terminal pencil (pencil indistinct in $O$. sydandersoni). Specimens of $O$. sydandersoni approach those of $O$. roberti and $O$. trinitatis in size but average smaller in most dimensions (table 6). Noteworthy are the longer, broader rostra in examples of $O$. roberti and $O$. trinitatis (truncate in $O$. sydandersoni), heavier supraorbital shelf with a distinct bead (incipient bead in $O$. sydandersoni), and longer bony 


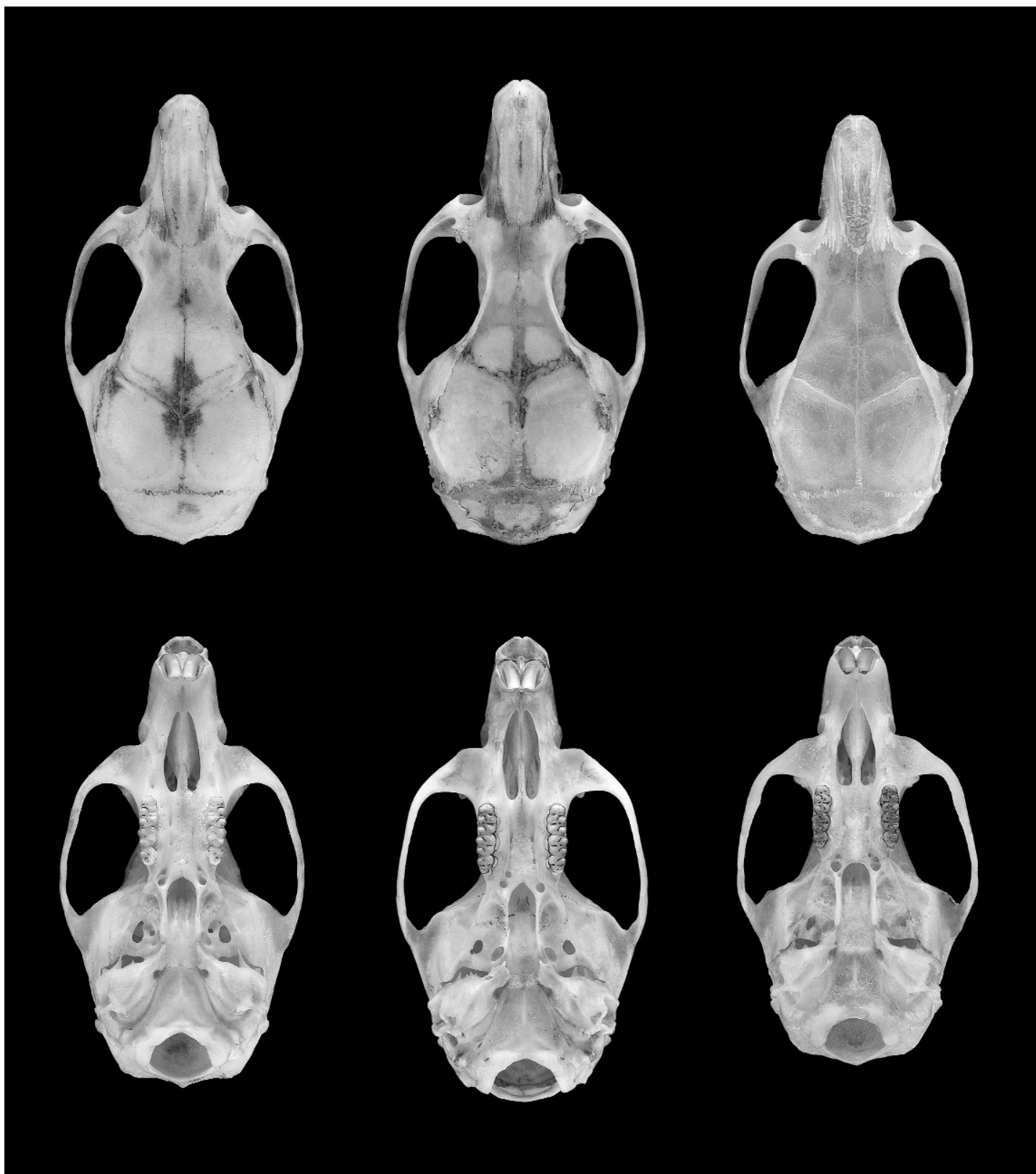

Fig. 4. Dorsal (top row) and ventral (bottom row) cranial views (ca. $2 \times$ ) of adult Oecomys representing the three species with a derived carotid circulatory pattern: left pair, O. concolor (USNM 374325, ONL = $31.9 \mathrm{~mm}$ ), an old adult female from Venezuela, Amazonas, Boca Mavaca, $185 \mathrm{~m}$; middle pair, O. mamorae $(\mathrm{AMNH} 260420, \mathrm{ONL}=33.0 \mathrm{~mm})$, an adult female from Bolivia, Santa Cruz, $3.5 \mathrm{~km}$ W Estación Pailón, $300 \mathrm{~m}$; right pair, O. sydandersoni (USNM 584561, ONL $=30.5 \mathrm{~mm}$ ), new species, an adult female from Bolivia, Santa Cruz, $3 \mathrm{~km}$ NE El Refugio. 


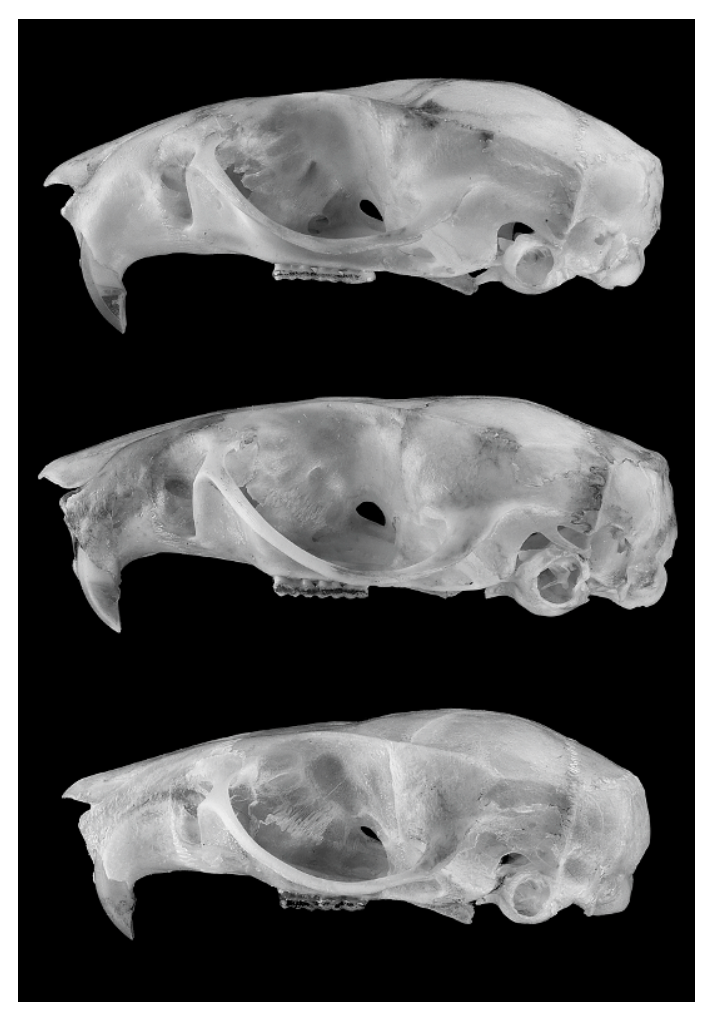

Fig. 5. Lateral view (ca. $2 \times$ ) of adult crania of the three species of Oecomys with a derived carotid circulatory pattern (same specimens as depicted in fig. 4): top, $O$. concolor; middle, O. mamorae; and bottom, $O$. sydandersoni, new species.

palate that extends forward beyond the M1s (shorter palate terminates approximately equal with the anterior border of the M1s in O. sydandersoni). The expansive bony palate in these two species inversely correlates with their shorter incisive foramina, which end anterior to the level of the front root of the M1s. Their incisive foramina are also shaped differently, lacking the posterior widening and blunt ends characteristic of $O$. sydandersoni. The distinctive dorsal pelage of $O$. trinitatisdeep $(8-10 \mathrm{~mm})$, palpably luxuriant, and lustrous - at once separates it from examples of $O$. sydandersoni, as well as those of $O$. bicolor and $O$. roberti. Moreover, the ventrum of $O$. trinitatis is darker gray, the hairs often tipped with buff, its caudal hairs are longer, and, as in $O$. bicolor, the tail possesses a more noticeable terminal pencil compared with $O$. sydandersoni. The degree of caudal hairiness and pencil development are comparable in $O$. sydandersoni and $O$. roberti, but the tail of the latter is longer and its dorsal pelage is shorter (3-5 $\mathrm{mm}$ in contrast to $5-7 \mathrm{~mm}$ in $O$. sydandersoni).

Ecological Notes: At the type locality of El Refugio Huanchaca, Emmons and associates captured 22 of 23 individuals of $O$. sydandersoni in open savanna characterized by a mosaic of long grasses and smaller clumps of woody vegetation (fig. 7). The grassland is deeply flooded by standing water (ca. $0.5 \mathrm{~m}$ ) for $1-4$ months during the wet season (December-March), and the woody vegetation grows on elevated mounds or hummocks originally formed around termite nests within the grassland. Because cattle no longer graze within the park and the wet grasslands tend to suppress fires, the woody vegetation on these hummocks is dense and well developed, with tall trees in the center and many woody vines. Examples of $O$. sydandersoni were uniformly collected within the large forested hummocks in snap traps or Sherman live traps placed above ground, up to $2.5 \mathrm{~m}$ high on vines, trunks, or branches within arm's reach. A single individual was captured in closed riverine forest, taken at $1.5 \mathrm{~m}$ height on a vine in a shrub along the river's edge.

Most $O$. sydandersoni were captured in 1998, when 21 individuals were obtained in the woody hummocks during 1430 trap-nights of collecting effort, along with the forest species Hylaeamys acritus (13), Proechimys longicaudatus (16), and Marmosa murina (1). Four other oryzomyine species (Cerradomys maracajuensis, Holochilus sciureus, Oligoryzomys microtis, Pseudoryzomys simplex) and one akodont (Necromys lenguarum) were captured in the surrounding grassland matrix. We find it noteworthy that $O$. sydandersoni was the only arboreal cricetid rodent caught in these woodland islands, that it was the most abundant rodent in that habitat, and that its occurrence was nearly confined to that patchy habitat. Emmons and Bolivian colleagues have tallied over 30,000 trap-nights of survey in nearby habitats, including over 11,000 trapnights in contiguous semideciduous forests, and captured only a single $O$. sydandersoni. They have failed to secure the species in dryground savanna woodland that lacks dense 


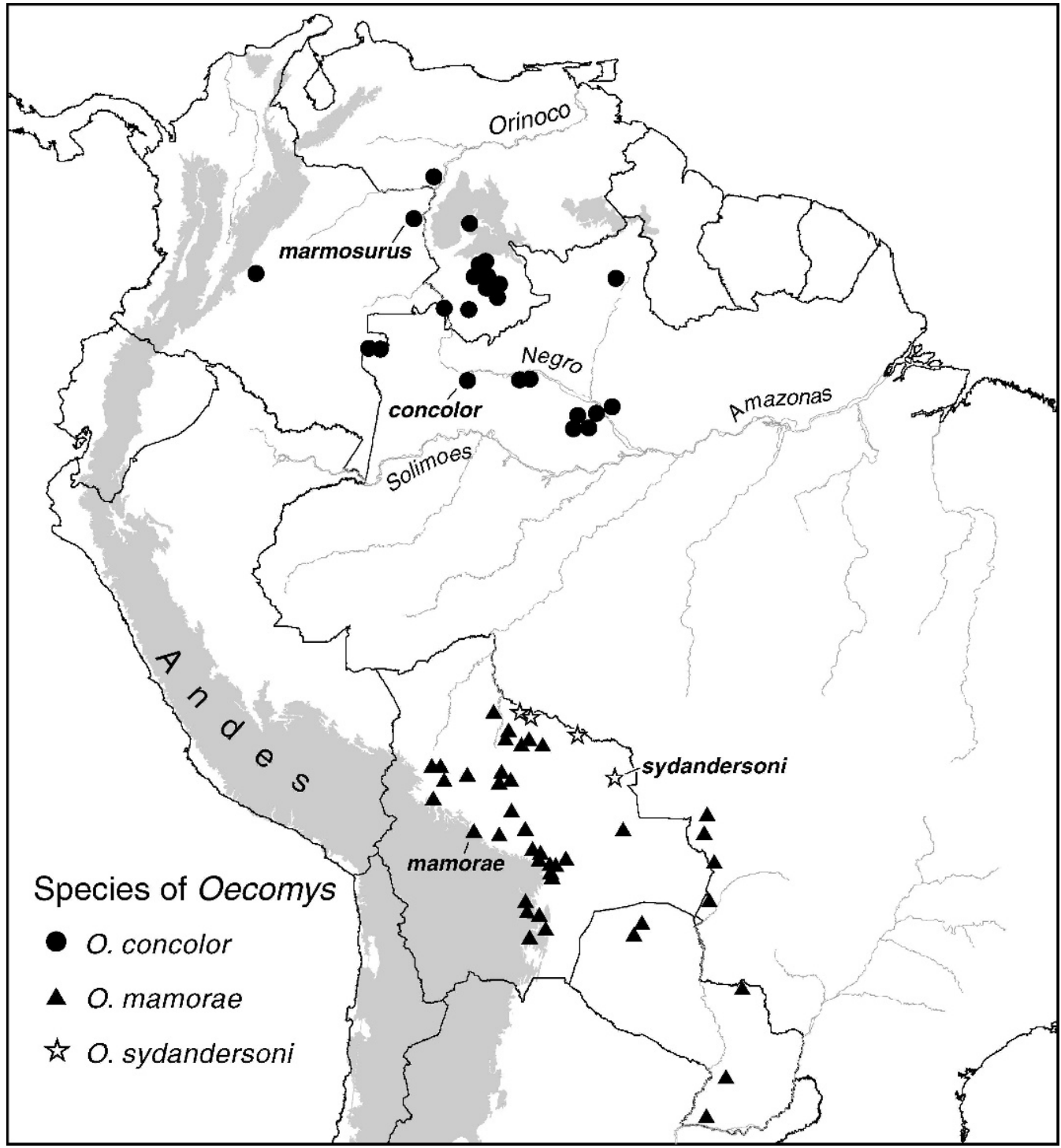

Fig. 6. Distributions of the three species of Oecomys known to possess a derived carotid circulatory pattern $(O$. concolor, $O$. mamorae, $O$. sydandersoni, new species). Type localities are indicated by short lines from the four species-group epithets considered herein (marmosurus, a junior synonym of $O$. concolor). Gray-shaded areas denote elevations above 1000 meters in the Andean cordilleras and Guianan highlands.

tree clumps (Cerrado proper), or in sporadically flooded "termite" savannas that contain many small shrubs and only small wooded hummocks $(<10 \mathrm{~m}$ across $)$. Three other species of Oecomys - O. bicolor, O. roberti, and $O$. trinitatus - were obtained in the adjacent, continuous-canopied, semideciduous forests.

These observations portray $O$. sydandersoni as a fairly narrow habitat specialist with a geographically restricted distribution. Such characteristics would perhaps account for its heretofore escape from the eyes of taxonomists and present rarity in collections. As its distribution is so far known, $O$. sydandersoni joins other species with limited geographic ranges that have been recently documented from extreme eastern Bolivia, in the Parque Nacional Noel Kempff Mercado or its vicin- 
TABLE 5

Occurrence of Alisphenoid Struts

$(-/-=$ struts absent both sides; $-/+=$ strut present on one side; $+/+=$ struts present both sides.)

\begin{tabular}{lrrr}
\hline & \multicolumn{3}{c}{ Alisphenoid Struts } \\
\cline { 2 - 4 } Species and Country & $-l-$ & $-l+$ & $+/+$ \\
\hline O. concolor & 1 & 0 & 25 \\
$\quad$ Brazil & 0 & 1 & 0 \\
Colombia & 0 & 0 & 18 \\
$\quad$ Venezuela & 1 & 1 & 43 \\
$\quad$ Totals & & & \\
O. mamorae & 29 & 1 & 0 \\
$\quad$ Bolivia & 1 & 0 & 0 \\
Brazil & 7 & 0 & 0 \\
Paraguay & 37 & 1 & 0 \\
$\quad$ Totals & & & \\
O. sydandersoni & 1 & 2 & 23 \\
$\quad$ Bolivia & & & \\
\hline
\end{tabular}

ity. These include the forest oryzomyine Hylaeamys acritus (Emmons and Patton, 2005), the akodonts Juscelinomys huanchacae and J. guaporensis (Emmons, 1999), and the rare marsupial Cryptonanus unduaviensis (Voss et al., 2005), which has been collected in the grassland matrix that surrounds the woodland patches inhabited by $O$. sydandersoni (Emmons et al., 2006). Whether the restricted ranges apparent for this group of species reflect a common historical response to the interplay of ecological change and biogeographic events in eastern Bolivia invites further research (Emmons et al., 2006).

REMARKS: The condition of the basal carotid arterial circulation in $O$. sydandersoni, $O$. concolor, and $O$. mamorae offers a morphological synapomorphy that suggests their closer relationship relative to other species of Oecomys. Such a provisional kinship hypothesis is encouraged by independent and combined analyses of IRBP sequences and morphological traits among oryzomyines (Weksler, 2003, 2006), in which the sistergroup pairing of $O$. concolor and $O$. mamorae was consistently and strongly supported among the five exemplars of Oecomys studied (other species included $O$. bicolor, $O$. catherinae, and $O$. trinitatis). The molecular voucher that Weksler called O. mamorae (MVZ 155005 from Peru, Amazonas, Río Cenepa), however, proves to be an example of $O$. roberti (identified by GGM and reconfirmed by J.L. Patton), a species with a complete carotid circulatory pattern (table 1 ). Confidence in the sister-group relationship of $O$. concolor and $O$. mamorae is thus eroded based on Weksler's data. Our foremost purpose in documenting the carotid pattern displayed by all Oecomys type specimens (table 1) was to constrain the differential diagnosis of the new species from Bolivia with respect to the most morphologically similar species currently recognized (Musser and Carleton 2005). In addition to possession of the same carotid circulatory plan, the resemblance of $O$. concolor and $O$. sydandersoni is striking, as conveyed by the earlier tentative identification of the few known Bolivian specimens as $O$. concolor (Musser and Carleton, 1993). The fine series later obtained by Emmons allowed morphological and morphometric confirmation of the two as valid species and appreciation of their approximately equivalent level of differentiation from $O$. mamorae (fig. 3), the third species of Oecomys known to possess the apomorphic carotid condition. Whether the derived carotid arterial pattern constitutes a synapomorpy of these three species or evolved independently will require further molecular and morphological studies based on broader taxon sampling within the genus and among other oryzomyines.

ETymology: The first three examples of $O$. sydandersoni were collected by Sydney Anderson (fig. 8) and members of his field team in 1964 and 1965, along the Río Iténez in eastern Bolivia. As a fresh-faced assistant curator in 1963, he had revived the earlier natural history explorations in Bolivia undertaken for the American Museum of Natural History, notably those of Anthony and Tate in the 1920s (see chronology of mammalian inventory in Anderson, 1997). Over the next three decades, Syd and his field collaborators amassed impressive series of Bolivian mammals that he utilized in numerous taxonomic reports on this biotically rich but poorly understood country, culminating in his weighty treatise (Anderson, 1997) on the "Mammals of Bolivia, Taxonomy and Distribution." All the while, he made these collections available to any serious scientist 
TABLE 6

External and Craniodental Measurements of the Four Species of Oecomys Collected in the Parc Nacional Noel Kempff Mercado, Eastern Bolivia

(Sample statistics include the mean, \pm 1 standard deviation, and the observed range.)

\begin{tabular}{|c|c|c|c|c|}
\hline Variable & $\begin{array}{l}\text { O. bicolor }{ }^{\mathrm{a}} \\
(N=7,8)\end{array}$ & $\begin{array}{l}\text { O. sydandersoni } \\
(N=21-23)\end{array}$ & $\begin{array}{l}\text { O. roberti }{ }^{\mathrm{b}} \\
(N=4,6)\end{array}$ & $\begin{array}{l}\text { O. } \text { trinitatis }^{\mathrm{c}} \\
(N=3,4)\end{array}$ \\
\hline TOTL & $\begin{array}{c}211.8 \pm 23.4 \\
172-240\end{array}$ & $\begin{array}{c}257.9 \pm 16.7 \\
233-290\end{array}$ & $\begin{array}{c}273.5 \pm 22.3 \\
237-295\end{array}$ & $\begin{array}{c}260.7 \pm 17.6 \\
241-275\end{array}$ \\
\hline TL & $\begin{array}{c}103.9 \pm 10.8 \\
87-122\end{array}$ & $\begin{array}{c}132.8 \pm 8.4 \\
115-145\end{array}$ & $\begin{array}{c}142.2 \pm 13.1 \\
127-160\end{array}$ & $\begin{array}{c}135.3 \pm 3.8 \\
131-138\end{array}$ \\
\hline HFL & $\begin{array}{c}19.4 \pm 1.0 \\
18-21\end{array}$ & $\begin{array}{c}24.1 \pm 1.7 \\
21-27\end{array}$ & $\begin{array}{c}25.7 \pm 1.7 \\
24-28\end{array}$ & $\begin{array}{c}26.0 \pm 1.1 \\
25-27\end{array}$ \\
\hline EL & $\begin{array}{c}14.5 \pm 0.5 \\
14-15\end{array}$ & $\begin{array}{c}16.4 \pm 1.1 \\
15-19\end{array}$ & $\begin{array}{c}15.8 \pm 1.0 \\
14-17\end{array}$ & $\begin{array}{c}17.3 \pm 1.7 \\
15-19\end{array}$ \\
\hline WT & $\begin{array}{c}29.9 \pm 8.1 \\
20-43\end{array}$ & $\begin{array}{c}44.9 \pm 7.8 \\
30-57\end{array}$ & $\begin{array}{c}50.5 \pm 18.1 \\
34-86\end{array}$ & $\begin{array}{c}45.8 \pm 8.7 \\
33-52\end{array}$ \\
\hline ONL & $\begin{array}{r}26.8 \pm 1.3 \\
24.6-27.8\end{array}$ & $\begin{array}{r}29.8 \pm 1.2 \\
27.7-32.0\end{array}$ & $\begin{array}{r}31.9 \pm 1.5 \\
29.6-33.7\end{array}$ & $\begin{array}{r}30.7 \pm 1.6 \\
28.5-32.0\end{array}$ \\
\hline ZB & $\begin{array}{r}14.1 \pm 0.8 \\
12.9-15.1\end{array}$ & $\begin{array}{r}16.5 \pm 0.6 \\
15.3-17.6\end{array}$ & $\begin{array}{r}16.7 \pm 0.9 \\
15.1-17.6\end{array}$ & $\begin{array}{r}16.1 \pm 0.9 \\
15.1-17.3\end{array}$ \\
\hline BBC & $\begin{array}{r}11.1 \pm 0.4 \\
10.5-11.7\end{array}$ & $\begin{array}{r}11.8 \pm 0.3 \\
11.3-12.4\end{array}$ & $\begin{array}{r}12.1 \pm 0.2 \\
11.9-12.4\end{array}$ & $\begin{array}{r}11.8 \pm 0.4 \\
11.4-12.3\end{array}$ \\
\hline $\mathrm{DBC}$ & $\begin{array}{c}8.4 \pm 0.2 \\
8.1-8.7\end{array}$ & $\begin{array}{c}9.1 \pm 0.3 \\
8.5-9.7\end{array}$ & $\begin{array}{c}9.1 \pm 0.5 \\
8.3-9.6\end{array}$ & $\begin{array}{c}9.0 \pm 0.2 \\
8.9-9.3\end{array}$ \\
\hline $\mathrm{BOC}$ & $\begin{array}{c}5.9 \pm 0.2 \\
5.7-6.3\end{array}$ & $\begin{array}{c}6.5 \pm 0.1 \\
6.3-6.8\end{array}$ & $\begin{array}{c}6.6 \pm 0.1 \\
6.4-6.7\end{array}$ & $\begin{array}{c}6.5 \pm 0.1 \\
6.4-6.6\end{array}$ \\
\hline IOB & $\begin{array}{c}4.7 \pm 0.2 \\
4.3-4.9\end{array}$ & $\begin{array}{c}5.3 \pm 0.3 \\
4.8-5.7\end{array}$ & $\begin{array}{c}5.5 \pm 0.2 \\
5.2-5.7\end{array}$ & $\begin{array}{c}5.1 \pm 0.3 \\
4.9-5.6\end{array}$ \\
\hline LR & $\begin{array}{c}7.7 \pm 0.6 \\
6.6-8.3\end{array}$ & $\begin{array}{c}8.4 \pm 0.5 \\
7.5-9.1\end{array}$ & $\begin{array}{r}9.7 \pm 0.4 \\
9.2-10.3\end{array}$ & $\begin{array}{c}9.5 \pm 0.6 \\
8.6-9.9\end{array}$ \\
\hline BR & $\begin{array}{c}4.9 \pm 0.3 \\
4.4-5.2\end{array}$ & $\begin{array}{c}5.5 \pm 0.3 \\
4.7-6.2\end{array}$ & $\begin{array}{c}5.9 \pm 0.2 \\
5.7-6.1\end{array}$ & $\begin{array}{c}5.9 \pm 0.5 \\
5.2-6.4\end{array}$ \\
\hline PPL & $\begin{array}{c}9.4 \pm 0.7 \\
8.1-9.9\end{array}$ & $\begin{array}{r}10.3 \pm 0.5 \\
9.2-11.4\end{array}$ & $\begin{array}{r}11.1 \pm 1.0 \\
9.6-12.7\end{array}$ & $\begin{array}{r}10.4 \pm 0.6 \\
9.7-11.0\end{array}$ \\
\hline BPL & $\begin{array}{c}4.4 \pm 0.4 \\
3.8-4.9\end{array}$ & $\begin{array}{c}5.6 \pm 0.3 \\
4.9-6.0\end{array}$ & $\begin{array}{c}6.3 \pm 0.2 \\
6.1-6.7\end{array}$ & $\begin{array}{c}6.3 \pm 0.5 \\
5.7-6.8\end{array}$ \\
\hline LIF & $\begin{array}{c}4.5 \pm 0.3 \\
3.8-4.9\end{array}$ & $\begin{array}{c}5.4 \pm 0.3 \\
4.9-5.8\end{array}$ & $\begin{array}{c}5.2 \pm 0.4 \\
4.5-5.7\end{array}$ & $\begin{array}{c}5.1 \pm 0.3 \\
4.7-5.4\end{array}$ \\
\hline BIF & $\begin{array}{c}2.1 \pm 0.1 \\
1.9-2.2\end{array}$ & $\begin{array}{c}2.6 \pm 0.2 \\
2.2-2.8\end{array}$ & $\begin{array}{c}2.5 \pm 0.2 \\
2.3-2.8\end{array}$ & $\begin{array}{c}2.3 \pm 0.1 \\
2.2-2.4\end{array}$ \\
\hline LD & $\begin{array}{c}6.7 \pm 0.6 \\
5.7-7.3\end{array}$ & $\begin{array}{c}7.7 \pm 0.5 \\
6.8-8.7\end{array}$ & $\begin{array}{c}8.3 \pm 0.4 \\
7.7-8.9\end{array}$ & $\begin{array}{c}7.6 \pm 0.6 \\
6.9-8.2\end{array}$ \\
\hline BBP & $\begin{array}{c}4.9 \pm 0.3 \\
4.5-5.2\end{array}$ & $\begin{array}{c}5.7 \pm 0.2 \\
5.2-6.2\end{array}$ & $\begin{array}{c}5.8 \pm 0.2 \\
5.6-6.1\end{array}$ & $\begin{array}{c}5.9 \pm 0.3 \\
5.5-6.1\end{array}$ \\
\hline BZP & $\begin{array}{c}2.2 \pm 0.3 \\
1.8-2.7\end{array}$ & $\begin{array}{c}2.9 \pm 0.2 \\
2.5-3.2\end{array}$ & $\begin{array}{c}2.8 \pm 0.4 \\
2.1-3.3\end{array}$ & $\begin{array}{c}3.3 \pm 0.3 \\
3.0-3.7\end{array}$ \\
\hline CLM & $\begin{array}{c}3.75 \pm 0.14 \\
3.57-3.93\end{array}$ & $\begin{array}{c}4.57 \pm 0.14 \\
4.35-4.90\end{array}$ & $\begin{array}{c}4.76 \pm 0.23 \\
4.48-5.15\end{array}$ & $\begin{array}{c}4.80 \pm 0.18 \\
4.64-5.05\end{array}$ \\
\hline
\end{tabular}


TABLE 6

(Continued)

\begin{tabular}{|c|c|c|c|c|}
\hline Variable & $\begin{array}{l}\text { O. bicolor }{ }^{\mathrm{a}} \\
(N=7,8)\end{array}$ & $\begin{array}{l}\text { O. sydandersoni } \\
\quad(N=21-23)\end{array}$ & $\begin{array}{l}\text { O. roberti }{ }^{\mathrm{b}} \\
(N=4,6)\end{array}$ & $\begin{array}{l}\text { O. } \text { trinitatis }^{\mathrm{c}} \\
(N=3,4)\end{array}$ \\
\hline WM1 & $\begin{array}{c}1.09 \pm 0.04 \\
1.05-1.17\end{array}$ & $\begin{array}{c}1.32 \pm 0.05 \\
1.25-1.40\end{array}$ & $\begin{array}{c}1.36 \pm 0.06 \\
1.28-1.46\end{array}$ & $\begin{array}{c}1.41 \pm 0.08 \\
1.35-1.53\end{array}$ \\
\hline
\end{tabular}

${ }^{a}$ Bolivia, Santa Cruz, Parque Nacional Noel Kempff Mercado, 2.5 km NE El Refugio (MNK-LHE 1561; MNK-VCC 13, 20, 132; USNM 584546-584549).

${ }^{\mathrm{b}}$ Bolivia, Santa Cruz, Parque Nacional Noel Kempff Mercado, 2.5 km NE El Refugio (MNK-LHE 1658, 1669, 1681, 1685; MNK-VCC 9; USNM 584550, 584551).

'Bolivia, Santa Cruz, Parque Nacional Noel Kempff Mercado, Los Fierros (MNK-LHE 1565, 1682; USNM 584552, 584553).

who needed to examine Bolivian specimens and was especially kind in allowing us unrestricted access to oryzomyine rodents, the results of which found their way into our own publications. Such selflessness and sterling ethics are typical of Syd. In the opening paragraph to his 1997 work, Syd wrote, "This work is dedicated to the hypothesis-testers of this world. Everything concluded is subject to further testing" (his laconic drawl, tinged with his gently prodding humor and punctuated by a trailing chortle, permeates this passage in our mind's ear). New species descriptions form the keystone to all biological hypotheses, and in the spirit of testing one of his conclusions, we are pleased to name this handsome Bolivian endemic of Oecomys in his honor. The species name is thus a patronym in the genitive singular, sydandersoni formed by combining the individual's familiar name ("Syd") and surname.

\section{Oecomys concolor (Wagner)}

Hesperomys concolor Wagner, 1845: 147 (type locality: Brazil, Amazonas, Rio Curicuriari, a tributary of the upper Rio Negro, below São Gabriel [as amplified by Hershkovitz, 1960: 547]; holotype: NMW B482).

[Oryzomys (Orzyomys)] concolor: Tate, 1932: 3 (name combination, taxonomic history).

Oryzomys (Oecomys) concolor concolor: Hershkovitz, 1960: 545 (genus-group revision, retention as valid species and nominotypical subspecies).

Oecomys concolor: Gardner and Patton, 1976: 13 (name combination, karyotype).

Rhipidomys marmosurus Thomas, 1899: 378 (type locality: Colombia, Vichada, middle Río Orinoco, Maipures; holotype: BMNH 1899.9.11.38).

[Oryzomys (Oecomys)] marmosurus: Thomas, 1906a: 445 (name combination, allocation to new subgenus).
O[ecomys] marmosurus: Thomas, 1910: 187 (name combination).

Oryzomys marmosurus: Ellerman, 1941: 358 (name combination).

Oryzomys (Oecomys) concolor concolor: Hershkovitz, 1960: 546 (subgeneric revision, marmosurus allocated as full synonym).

Oecomys concolor: Musser and Carleton, 1993: 716 (name combination, marmosurus listed as synonym without indication of rank).

Emended Diagnosis: A species of Oecomys (Sigmodontinae: Oryzomyini) characterized by a combination of medium-large size $(\mathrm{HFL} \approx 26-28 \mathrm{~mm}, \mathrm{ONL} \approx 31-33 \mathrm{~mm})$, relatively long tail $(\mathrm{TL} \approx 140-155 \mathrm{~mm}$ ), very short pelage, relatively narrow incisive foramina, presence of alisphenoid struts, and a derived carotid circulatory pattern (skull lacking squamosal-alisphenoid groove, sphenofrontal foramen, and posterolateral groove on the parapterygoid plate; posterior opening to the alisphenoid canal compressed; stapedial foramen absent; groove dorsally crossing the parapterygoid plate present).

Distribution: Lowland rainforest to the north of the rios Amazonas-Solimões in northwestern Brazil and to the south of the Río Orinoco in eastern Colombia and southern Venezuela (fig. 6). Known elevational range sea level to $400 \mathrm{~m}$.

REMARKS: In 1848, Wagner amplified his initial brief diagnosis (Wagner, 1845) of concolor under Hesperomys, a catchall genus of the middle 1800s whose definition and contents were nearly equivalent to the subfamily Sigmodontinae as its taxonomic boundaries are understood today (translation below by E. Brothers; see appendix 2 for original Latin and German text): 


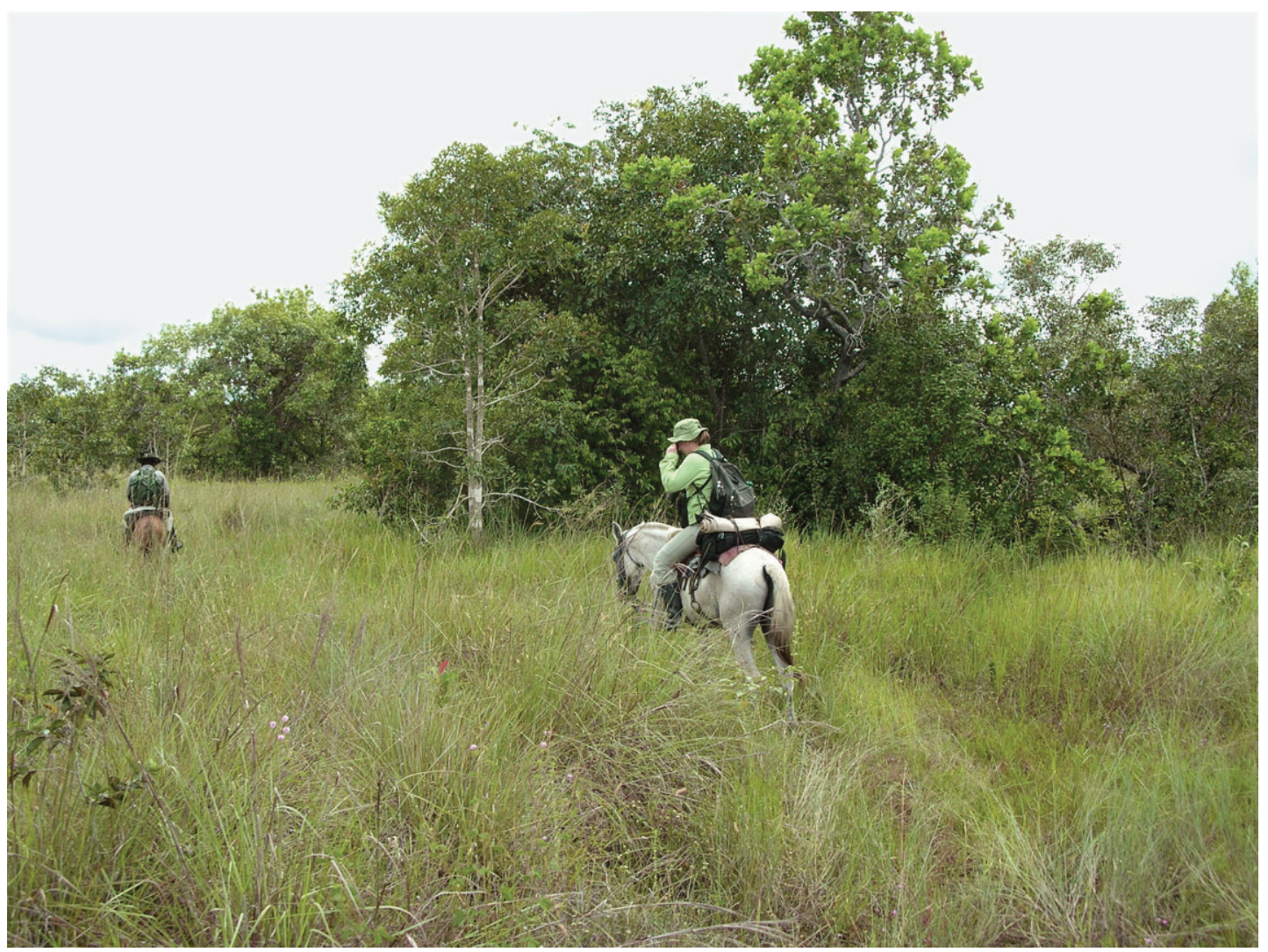

Fig. 7. Characteristic habitat at the type locality of Oecomys sydandersoni in the Parque Nacional Noel Kempff Mercado, eastern Bolivia. Individuals of O. sydandersoni were captured only in the low-canopied forested patches that grow on elevated hummocks, but not within the surrounding, seasonally flooded grasslands. Photographed by L.H. Emmons in February 2007.

5. Hesperomys concolor Wagner. The monochromatic "scharrmaus."

$H$ [esperomys concolor is $]$ tawny, abruptly white below, with feet becoming darker; tail naked and as long as the body; with the hairs of the belly a uniform color.

Hesperomys concolor. A. Wagner in Archiv für Naturgeschichte 1845: 147.

We have viewed this species initially as a modification of Hesperomys Anguya; after I had made a careful comparison with the latter, it appeared more proper to me to consider it a species. It is in all ways very closely related to $H$. Anguya, but the coloring of the dorsum is far livelier, mixed with more red and sprinkled with black. The underside, which is a beautiful white, has hair that is purely of one color, in contrast to the two- colored H. Anguya; furthermore, the gray coloring of the cheeks is absent and the feet are covered with brownish hairs; the naked tail, with only short fine hairs, has a dark coloring. The whiskers are black and the ears are haired in the same manner as $H$. Anguya.

\begin{tabular}{|c|c|c|}
\hline & H. concolor & H. Anguya \\
\hline Body & $4^{\prime \prime} 10^{\prime \prime \prime}$ & $5^{\prime \prime} 8^{\prime \prime \prime}$ \\
\hline Tail & 49 & 56 \\
\hline Ear & $\begin{array}{lll}0 & 62 / 2 \text { [sic] }\end{array}$ & 08 \\
\hline Hindfoot & 10 & 13 \\
\hline
\end{tabular}

Natterer collected this species at the Curicuriari River in northwestern Brazil.

After Wagner's description, concolor remained a forgotten name in the early nomenclatural history of oryzomyine rodents until 


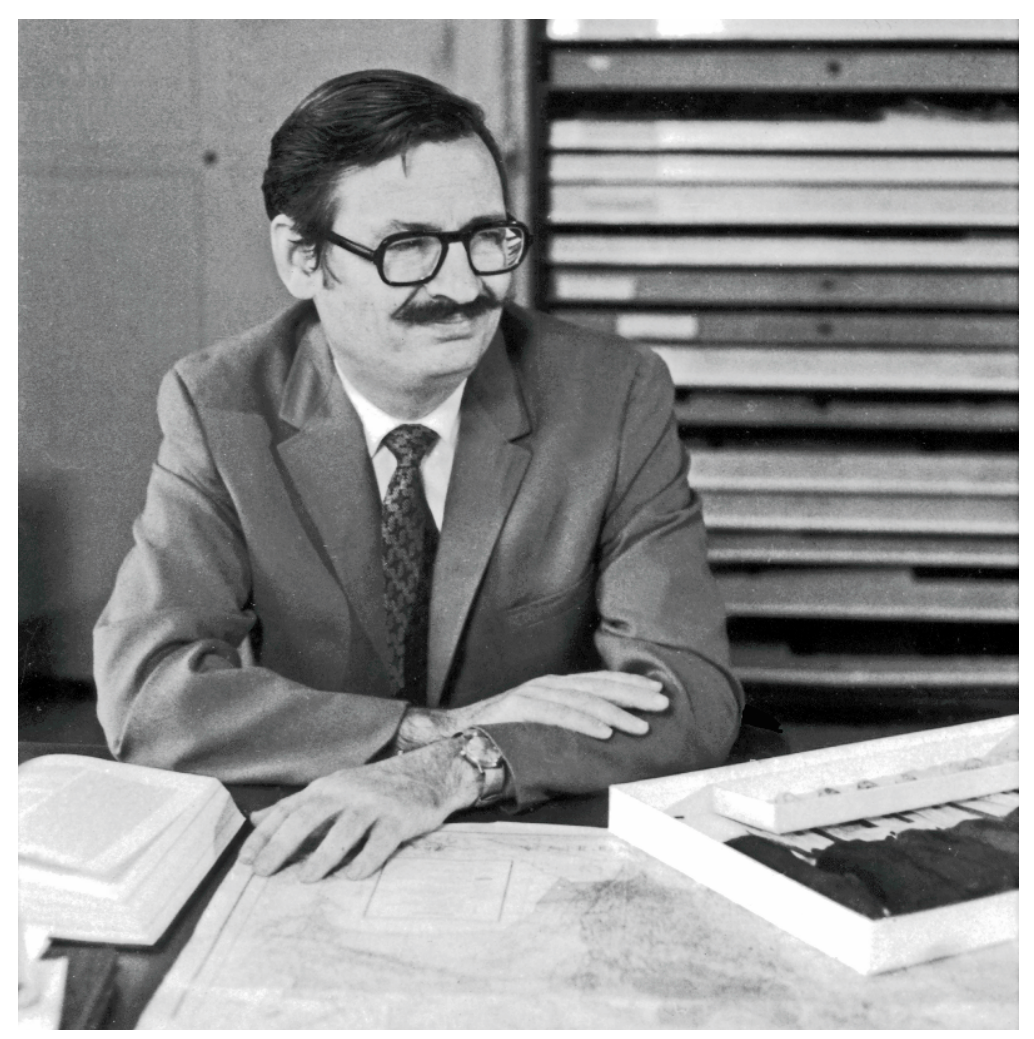

Fig. 8. Dr. Sydney Anderson, Curator of Mammals, American Museum of Natural History (1961-1992, as photographed in October 1974). The first specimens of Oecomys sydandersoni (initially reported as $O$. concolor) were collected during Anderson's first collecting trips to Bolivia in 1964-1965 and represent just some of the novel diversity that he documented in his impressive faunal synthesis (Anderson, 1997), "Mammals of Bolivia, Taxonomy and Distribution."

Tate (1932) associated it with Oryzomys (Oryzomys). Hershkovitz (1960) correctly recognized concolor Wagner as a species of Oecomys, ranked as subgenus, but had not examined any type material. Musser's study of the type specimen of concolor (NMW B482; table 7) in 1992 supports Hershkovitz's genusgroup association of the name, the oldest epithet assignable to Oecomys. The type is a young adult (sex indeterminate), with only moderate wear on the molars but in full adult pelage. Aspects of the holotype indicate that it was first preserved in alcohol and later stuffed and converted to a museum specimen. The tail is brittle but intact; the pinnae are somewhat tattered and paler than those observed in the recently collected Venezuelan series. The upperparts of the holotype are closely similar in fur length, texture, and color to material from the lowlands of Venezuela except that they are slightly redder, probably a result of initial preservation in alcohol. The chin and throat are gray, and the rest of the underparts are white except along the flanks, where the basal portions of the hairs are pale gray. As emphasized by his designation of the specific name, Wagner was impressed by the all-white underparts of the specimen before him, but coloration of the ventral pelage does vary within the series that we have examined. Many specimens possess small to broad expanses of gray over the middle abdomen, and some exhibit a strong overwash of buffy-tipped hairs; the dorsal-ventral pelage contrast is weakly defined in the latter condition. Impressions of the carotid branching preserved on the skull of the type specimen disclose a derived configuration-no spheno- 
frontal foramen or squamosal-alisphenoid groove, minute stapedial foramen, diagonal groove across dorsal surface of parapterygoid bone - the same traits that we have uniformly observed in all other specimens that we identify as $O$. concolor. Further, the type skull bears a strong alisphenoid strut on both sides, a condition observed in nearly all specimens of $O$. concolor examined (table 5).

As mentioned by Wagner, the specimen on which he based his new species was obtained by Johann Natterer (1787-1843), an Austrian naturalist and early collector of birds and mammals in the Amazon Basin. Kurt Bauer of the Naturhistorisches Museum Wien kindly provided additional information about Natterer's travels and the collecting site of the type (in litt. to GGM, 16 Jan 1984).

I found no information how far up the rio Curicuriari Natterer went, but all indications are, that he stopped just at the mouth or entered the lowest part. Oe. concolor seems to be the only mammal collected there, and the itinerary v. Pelzeln [August von Pelzeln, 1825-1891] provided in his work on Natterer's birds [Pelzeln, 1871] just mentions 5 August 1831 represented by a bird collected there. From his data ... and our notes, it is clear that J. Natterer stayed at least until 15th July at the Rio Vaupe/Uaupes and collected at Barcellos/Barcelos about $500 \mathrm{~km}$ downriver on the Rio Negro from August 23rd onward.

Thus, the standard coordinates for the mouth of the Río Curicuriari (appendix 1), a southern tributary of the Río Negro, may reasonably approximate the geographic source of Natterer's specimen and Wagner's type of Hesperomys concolor.

The holotype of marmosurus (BMNH 1899.9.11.38; table 7) possesses a bright ochraceous-tawny dorsum, resembling the more intensely colored specimens in the recent Venezuelan series. The belly is white overwashed with buff. The skull clearly exhibits the key traits of a derived carotid circulatory pattern and possesses well-developed alisphenoid struts on both sides.

The construct of $O$. concolor promulgated by Hershkovitz (1960) consisted of five subspecies (concolor, speciosus, superans, ro- berti, bahiensis) whose collective distribution matched that of the genus in lowland rainforest of Central and South America. The highly variable morphology and pantropical range of his form reflected its composite nature, which embraced, either entirely or in part, at least nine valid species among the synonyms (auyantepui, catherinae, concolor, flavicans, mamorae, roberti, speciosus, superans, trinitatis, as per Musser and Carleton, 2005). To our knowledge, only one speciesgroup epithet, marmosurus Thomas (1899), properly belongs as a subjective junior synonym of $O$. concolor (Wagner, 1845). Divorced of these other species, $O$. concolor sensu stricto is seen to exhibit a somewhat specialized morphology, with limited boundaries of variation, and this morphology has a very restricted distribution within the genus. The geographic occurrence of $O$. concolor is confined to the Rio Negro West subregion of northern Amazonia, an area of endemism delineated from phlyogeographic and distributional studies of neotropical birds (Cracraft and Prum, 1988; Stotz et al., 1996).

Specimens Examined: 63, as follows. BrazilAmazonas, Rio Curicuriari, a tributary of the upper Rio Negro, below São Gabriel (NMW B482, holotype of concolor); Ilha das Onças, left bank Rio Negro, $01^{\circ} 49^{\prime} 57^{\prime \prime} \mathrm{S} / 61^{\circ} 22^{\prime} 49^{\prime \prime} \mathrm{W}$ (INPA-JLP 16806, 16807, INPA-LC 168, 178, INPA-YL 161); Lago Meduini, left bank Rio Negro, $01^{\circ} 47^{\prime} 07^{\prime \prime} \mathrm{S} /$ $61^{\circ} 23^{\prime} 39^{\prime \prime} \mathrm{W}$ (INPA-JLP 16795, INPA-LC 176); Macaco, left bank Rio Jaú, $24 \mathrm{~m}, 02^{\circ} 05^{\prime} 01^{\prime \prime} \mathrm{S} /$ $62^{\circ} 07^{\prime} 21^{\prime \prime} \mathrm{W}$ (INPA-LC 124, 128, 137-139, INPAYL 127, 129, 131, 133); Macaco, right bank Rio Jaú, 02 04'30"S/62 06'21"W (INPA-YL 144, 146, INPA-LC 151, 154); vicinity of Comunidade Tambor, left bank Rio Jaú, $02^{\circ} 14^{\prime} \mathrm{S} / 62^{\circ} 26^{\prime} \mathrm{W}$ (INPA-MNFS 2038，2040，2051，2057，2059, 2060); Rio Uaupes, $2 \mathrm{~m}$ opposite Tahuapunta, $00^{\circ} 36^{\prime} \mathrm{N} / 69^{\circ} 11^{\prime} \mathrm{W}$ (AMNH 78630 ); Yavanari, right bank Rio Negro, $00^{\circ} 32^{\prime} \mathrm{S} / 64^{\circ} 49^{\prime} \mathrm{W}$ (AMNH 79400). Roraima, Rio Uraicoera (joins the Rio Tacutu to form the Rio Branco), $03^{\circ} 02^{\prime} \mathrm{N} / 60^{\circ} 29^{\prime} \mathrm{W}$ (BMNH 1933.12.4.5). Colombia-Meta, $18 \mathrm{~km}$ S San Juan de Arama, Los Micos, $1300 \mathrm{ft}$ (FMNH 87966, 87968). Vichada, middle Río Orinoco, Maipures (BMNH 1899.9.11.38 [holotype of marmosurus]). Venezuela-Amazonas, Río Cunucunuma, $48 \mathrm{~km}$ NW Esmeralda and $13 \mathrm{~km}$ SSW Belén, Acanaña (USNM 406021, 406022); Río Cunucunuma, $56 \mathrm{~km}$ NNW Esmeralda, Belén, $150 \mathrm{~m}$ (USNM 406013); $68 \mathrm{~km}$ SE Esmeralda, Boca Mavaca, $138 \mathrm{~m}$ (USNM 406014-406020), 
TABLE 7

External and Craniodental Measurements (in $\mathrm{mm}$ ) of the Type Specimens of Hesperomys concolor Wagner, Rhipidomys marmosurus Thomas, and Oryzomys mamorae Thomas

\begin{tabular}{lccc}
\hline \hline Variable & $\begin{array}{c}\text { concolor } \\
\text { NMW B482 }\end{array}$ & $\begin{array}{c}\text { marmosurus }^{\mathrm{a}} \\
\text { BMNH } 1899.9 .11 .38\end{array}$ & $\begin{array}{c}\text { mamorae }^{\mathrm{b}} \\
\text { BMNH }^{2}\end{array}$ \\
\hline HBL & - & 124 & 1300.8 .3 .21 \\
TL & - & 157 & 168 \\
HFL & - & $26(28)$ & 27 \\
EL & - & 18 & 20 \\
ONL & 29.2 & 33.8 & 33.1 \\
ZB & 15.9 & - & 17.5 \\
BBC & 13.3 & 12.6 & 12.6 \\
DBC & - & 9.1 & 9.2 \\
IOB & 5.0 & 5.8 & 5.1 \\
BOC & - & 6.9 & 7.3 \\
LR & 7.7 & 9.4 & 8.9 \\
BR & 5.7 & 6.2 & 4.8 \\
PPL & - & 11.3 & 10.8 \\
BPL & 6.0 & 6.6 & 6.2 \\
LIF & 4.8 & 5.4 & 5.9 \\
BIF & 2.4 & 2.5 & 2.7 \\
LD & 7.4 & 8.2 & 7.9 \\
BBP & 5.8 & 6.3 & 6.4 \\
BZP & 2.9 & 3.7 & 3.4 \\
CLM & 4.8 & 4.9 & 5.2 \\
WM1 & 1.3 & 1.3 & 1.5 \\
\hline
\end{tabular}

${ }^{a}$ External data as given by Thomas (1899).

${ }^{\mathrm{b}}$ External data as given by Thomas (1906b).

185 m (USNM 374322-374325); Río Manapiare, San Juan, 155 m (USNM 409862, 409863, 418444); Río Orinoco, Tamatama, 135 m (USNM 409880, 416712, 416713); Río Orinoco, Caño Derecho (stream meeting Río Orinoco on its right bank), $02^{\circ} 48^{\prime} \mathrm{N} / 65^{\circ} 14^{\prime} \mathrm{W}$ (AMNH 78069-78072, 78545); Río Casiquiare, $250 \mathrm{ft}, 02^{\circ} 48^{\prime} \mathrm{N} / 65^{\circ} 55^{\prime} \mathrm{W}$ (AMNH 77319); $12 \mathrm{mi} W$ Río Jawasu, left bank of Río Casiquiare, $01^{\circ} 58^{\prime} \mathrm{N}, 66^{\circ} 42^{\prime} \mathrm{W}$ (AMNH 77328); Río Casiquiare, El Merly, $03^{\circ} 05^{\prime} \mathrm{N} / 65^{\circ} 55^{\prime} \mathrm{W}$ (AMNH 78073, 78074). Apure, $60 \mathrm{~km}$ NE Puerto Páez, Cinaruco River, Hato Caribén, $76 \mathrm{~m}$ (USNM 374321).

\section{Oecomys mamorae (Thomas)}

Oryzomys (Oecomys) mamorae Thomas, 1906b: 445 (type locality-Bolivia, Cochabamba, Yungas, upper Río Mamoré, Mosetenes; holotype-BMNH 1900.8.3.21).

Oecomys mamorae: Osgood, 1916: 206 (name combination).

Oryzomys mamorae: Ellerman, 1941: 358 (name combination).

Oryzomys mamorae mamorae: Cabrera, 1961: 405 (retained as species, ranked as nominate subspecies).
Oryzomys concolor roberti: Hershkovitz, 1960: 559 (part, mamorae allocated as full subspecific synonym).

Oecomys concolor roberti: Anderson, 1985: 12 (part, marmorae listed as full synonym).

Emended Diagnosis: A species of Oecomys (Sigmodontinae: Oryzomyini) characterized by a combination of medium-large size (HBL $\approx 130-150 \mathrm{~mm}, \mathrm{HFL} \approx 25-29 \mathrm{~mm}$, $\mathrm{ONL} \approx 31-33 \mathrm{~mm}$ ), relatively long tail (TL $\approx 150-170 \mathrm{~mm}$ ), narrow interorbit and weakly developed supraorbital ridges, long and narrow incisive foramina, relatively short bony palate and simple posterolateral palatal pits, alisphenoid struts typically absent, and a derived carotid circulatory pattern (skull lacking squamosal-alisphenoid groove, sphenofrontal foramen, and posterolateral groove on the parapterygoid plate; posterior opening to the alisphenoid canal compressed; stapedial foramen absent; groove dorsally crossing the parapterygoid plate present).

Distribution: Subhumid and gallery forests in savanna and Chaco zones of central 
and eastern Bolivia, contiguous westcentral Brazil, and northern and eastern Paraguay (fig. 6). Known elevational range sea level to $2100 \mathrm{~m}$, most localities within 200-500 m.

REMARKs: The cranium of the type specimen of mamorae (BMNH 1900.8.3.21), an old adult female, exhibits the essential traits of a derived carotid pattern (no sphenofrontal foramen, stapedial foramen minute), yet it does retain shallow traces of the squamosalalisphenoid groove on the inner walls of the braincase. As in most specimens of $O$. mamorae that we have examined (table 5), the type lacks alisphenoid struts. Thomas (1906b: 446) critically contrasted his new form $O$. mamorae to marmosurus, here allocated as a junior synonym of $O$. concolor, and captured the consistent proportional differences that we have observed in the larger samples of each species now available: "the distinction of this animal [O. mamorae], which may be separated from its only equal in size, $O$. (Oe.) marmosurus, by its narrower interorbital region, less developed orbital ledges, and larger palatal foramina." The interorbital constriction (IOB) and long incisive foramina (LIF) correlate strongly with the first canonical variate that discriminates specimens of $O$. mamorae from those of $O$. concolor and $O$. sydandersoni (fig. 3; tables 3, 4, 7).

Following Thomas, O. mamorae had been retained as a distinctive species by most authors until Hershkovitz (1960) submerged it within his expansive view of $O$. concolor, as a full synonym of $O$. c. roberti. Hershkovitz's definition of the subspecies confused two distinctive species, O. roberti Thomas (1903) and $O$. mamorae Thomas (1906b), which are easily separable from one another and from $O$. concolor (Wagner) proper. Examples of $O$. roberti, like most other Oecomys, retain the complete carotid arterial pattern in contrast to the derived condition found in $O$. mamorae. Although the dorsal pelage of both species tends to be pale ochraceous-tawny and the venter mostly white, the cover hairs are typically shorter in $O$. roberti $(3-5 \mathrm{~mm}$ over the rump) than $O$. mamorae (7-9 $\mathrm{mm})$. In addition, the supraorbital shelf and posterolateral palatal pits are more pronounced in $O$. roberti. Specimens of $O$. roberti have been recorded in northern and easternmost Bolivia
(Anderson, 1997; Emmons et al., 2006), just peripheral to the range of $O$. mamorae (fig. 6), but the two species have yet to be discovered in sympatry.

Specimens of Oecomys have been recovered from owl pellets in northeastern Argentina, from the provinces of Chaco (Massoia and Fornes, 1965, as O. concolor) and Formosa (Pardiñas and Ramírez-Llorens, 2005, as $O$. sp.). By geographic proximity alone, these samples are plausibly referable to $O$. mamorae, but certain measurements reported for the fragmented crania of the Argentine form seem to run larger than $O$. mamorae proper from Bolivia (notably IOB, LIF, BIF, LD, WM1Pardiñas and Ramírez-Llorens, 2005: table 1). Critical review of variation within nominal $O$. mamorae and comparisons with the Argentine populations are required to verify their specific assignment. Such a review should include those populations documented in eastern Paraguay, to the east of the Paraguay River, reported as O. concolor (Myers, 1982) and here referred to $O$. mamorae based on our examinations.

Specimens Examined: 128, as follows. Bolivia-Beni, Baures (FMNH 117063-117066); Boca del Río Ibaré (AMNH 211749); Río Ibaré, $26 \mathrm{~km}$ from mouth (AMNH 211718, 211719, 211750-211752); Busurucucú, Yacuma Prov., 200 m (AMNH 263491); Lúcuma, 6 leagues S San Ramón (USNM 460430); Magdalena (FMNH 117055-117058); Río Beni, El Consuelo, $196 \mathrm{~m}$ (NHMS 153); Río Beni, Puerto Salinas, $226 \mathrm{~m}$ (NHMS 62-64, 74-77, 79, 80); Mamoré River (AMNH 211753); Río Mamoré, Marbán, $240 \mathrm{~m}$ (AMNH 129254, 129255); Mamoré, San Joaquín (FMNH 117053, 117059, 117067, 117068; USNM 391302); Río Tijamuchi, sea level (AMNH 262012); Yuatre (FMNH 117060, 117061); Km 35, NW of Yucumo, $253 \mathrm{~m}$ (AMNH 264769; MSB 68481). Chuquisaca, $2 \mathrm{~km}$ E Chuhuayacu, $1200 \mathrm{~m}$ (MSB 63355); Tomina Province, $40 \mathrm{~km}$ from Padilla, Tola Orko, $2100 \mathrm{~m}$ (USNM 271581, 271582, 271584 271587); Río Limón, 1300 m (MSB 63354); Tomina Province, Tihumayu (USNM 290906); Ticucha, Río Capirenda (FMNH 72890). Cochabamba, Boca Río Chapare, $825 \mathrm{ft}$ (ANSP 19405); Río Moile Ichilo (Inst. Roy. Sc. Nat. Belgium 20103, 25297); Todos Santos, $1300 \mathrm{ft}$ (AMNH 38520-38523, 38561, 38563-38566, 38568-38578, 40782-40786; FMNH 21520-21524); Yungas Prov., upper Río Mamoré, Mission Mosetenes (BMNH 1900.8.3.21 [holotype of mamorae], 1900.8.3.24). La Paz, $1 \mathrm{mi}$ W Puerto Linares (MSU 33018). Santa Cruz, Andrés Ibáñez Prov., Ayacucho (USNM 390655); Cordillera 
Prov., Basilio (USNM 390654); Buena Vista, 350, 450, and $500 \mathrm{~m}$ (AMNH 61776; BMNH 26.12.4.52, 28.2.9.39-28.2.9.42, 51.5.23.6; FMNH 25267, 25268, 51907, 51913, 51915); Cordillera Province, $5 \mathrm{~km}$ S Choreti, Camiri, $1000 \mathrm{~m}$ (CAS 13805; USNM 276602); $3.5 \mathrm{~km}$ W Estación Pailón, $300 \mathrm{~m}$ (AMNH 260420; MSB 55313); $3 \mathrm{~km} \mathrm{~N}$ and $7 \mathrm{~km}$ E Ingeniero Mora, 490-580 m (AMNH 247757); Punta Rieles (AMNH 263101-263104, 263366); San Rafael de Amboró, 400 m (AMNH 262013, 262014, 262119, 262099; MSB 56072); Velasco Prov., Santa Ana (USNM 390656, 391301); 15 km S Santa Cruz, 400 m (MSB 58648); Santa Cruz de la Sierra, 410 m (CM 2146, 2749); Río Yapacaní (FMNH 51914). Brazil-Mato Grosso, Caiçara (NMW B475); Descalvados, Uca (FMNH 26643). Mato Grosso do Sul, Fazenda Acurizal (USNM 531278); Río Paraguai, Urúcum de Corumbá (FMNH 26811). Paraguay-Amambay, Bella Vista, Colonia Sargento Duré, $3 \mathrm{~km}$ (by road) E Río Apa (MSB 70699, 70739). Chaco, $50 \mathrm{~km}$ WNW Fortín Madrejón, Cerro León (UMMZ 125456); 28 km WNW Mayor Pablo La Gorenza, edge Río La Gorenza (= Río Timane), San Alfredo (UCONN 19187-19189). Misiones, 40 km S San Ignacio (AMNH 234787). Paraguari, $17 \mathrm{~km} \mathrm{SW}$ Piribebuy, Saltos de Pirareta (UMMZ 133793).

\section{ACKNOWLEDGMENTS}

We acknowledge the curators and museum staff who graciously facilitated access to specimens through loans or collections visits over many years, in particular: Kurt Bauer (NMW); Paula Jenkins (BMNH); Sue McLaren (CM); Philip Myers (UMMZ); Bruce Patterson and William T. Stanley (FMNH); James L. Patton (MVZ); and Maria Rutzmoser (MCZ). Eric Brothers (AMNH) kindly translated Wagner's (1845) original German description of Hesperomys concolor, and Pat Brunauer (AMNH) located and shipped miscellaneous research materials to Musser. The cranial line drawings in figure 1 represent the artistic talent of Patricia J. Wynne, whose keen eye has once again captured the subtle intricacies of the muroid skull in an intelligible manner. We also thank John Steiner (Senior Photographer, NMNH Branch, Smithsonian Photographic Services), who undertook the cranial photography (figs. 4, 5), and Dan Cole (GIS Coordinator, NMNH Office of Information Technology), who supplied the geographic database of South America used for the preparation of the distribution map (fig. 6) and offered guidance in the application of ArcView. Their expert talents and special knowledge were critical to the preparation of this scientific communication. Finally, our communication benefitted from the helpful reviews of James L. Patton and Alexandre R. Percequillo. Any errors of omission or commission, of course, remain our own.

Emmons' field research in Bolivia represents a fruitful collaboration with the Museo de Historia Natural Noel Kempff Mercado, Santa Cruz, and numerous individuals have played vital roles in furthering this research. Damián Rumiz and Kathia Rivero helped with logistics and permits; Alan Weedon and the Weedon Foundation hosted studies at El Refugio Huanchaca; Ian and Barbara Phillips provided logistic support; and Norka Rocha and Veronica Chávez cheerfully provided field assistance. Emmons' fieldwork was also supported by the Douroucouli Foundation, the National Geographic Society, Wildlife Conservation Society, Amazon Conservation Association, and the W. Alton Jones Foundation. Research in Bolivia was undertaken under permits from the Servicio Nacional de Áreas Protegidas and the Dirección General de Biodiversidad y Áreas Protegidas, which kindly facilitated our studies.

\section{REFERENCES}

Allen, G.M., and T. Barbour. 1923. Mammals from Darien. Bulletin of the Museum of Comparative Zoology 45: 259-274.

Allen, J.A. 1904. New mammals from Venezuela and Colombia. Bulletin of the American Museum of Natural History 20(28): 327-335.

Allen, J.A. 1916. List of mammals collected in Colombia by the American Museum of Natural History expeditions, 1910-1915. Bulletin of the American Museum of Natural History 35(18): 191-238.

Anderson, S. 1985. Lista preliminar de mamíferos bolivianos. Academia Nacional de Ciencias de Bolivia Cuadernos 65: 5-16.

Anderson, S. 1997. Mammals of Bolivia, taxonomy and distribution. Bulletin of the American Museum of Natural History 231: 1-652.

Bugge, J. 1970. The contribution of the stapedial artery to the cephalic arterial supply in muroid rodents. Acta Anatomica 76: 313-336. 
Cabrera, A. 1961. Catálogo de los mamíferos de América del Sur. Revista del Museo Argentino de Ciencias Naturales "Bernardino Rivadavia" Ciencias Zoológicas 4(2): v-xxii, 309-732.

Carleton, M.D. 1980. Phylogenetic relationships in neotomine-peromyscine rodents (Muroidea) and a reappraisal of the dichotomy within New World Cricetinae. Miscellaneous Publications Museum of Zoology University of Michigan 157: 1-146.

Carleton, M.D., L.H. Emmons, L.K. Gordon, and D.E. Wilson. 1986. Mammal survey of the lower Rio Xingu, Pará, Brazil. Unpublished report, $26 \mathrm{pp}$.

Carleton, M.D., and G.G. Musser. 1984. Muroid rodents. In S. Anderson and J.K. Jones, Jr. (editors), Orders and families of Recent mammals of the world: 289-379. New York: John Wiley, $686 \mathrm{pp}$.

Carleton, M.D., and G.G. Musser. 1989. Systematic studies of oryzomyine rodents (Muridae, Sigmodontinae): a synopsis of Microryzomys. Bulletin of the American Museum of Natural History 191: 1-83.

Carleton, M.D., and G.G. Musser. 1995. Systematic studies of oryzomyine rodents (Muridae Sigmodontinae): definition and distribution of Oligoryzomys vegetus (Bangs, 1902). Proceedings of the Biological Society of Washington 108: 338-369.

Cracraft, J., and R.O. Prum. 1988. Patterns and processes of diversification: speciation and historical congruence in some neotropcial birds. Evolution 42: 603-620.

Ellerman, J.R. 1941. The families and genera of living rodents. Vol. II. Family Muridae. London: British Museum (Natural History), $690 \mathrm{pp}$.

Emmons, L.H. 1999. Two new species of Juscelinomys (Rodentia: Muridae) from Bolivia. American Museum Novitates 3280: 1-15.

Emmons, L.H., V. Chavez, N. Rocha, B. Phillips, I. Phillips, L.F.d. Aguila, and M.J. Swarner. 2006. The non-flying mammals of Noel Kempff Mercado National Park (Bolivia). Revista Boliviana de Ecología y Conservación Ambiental 19: 23-46.

Emmons, L.H., and F. Feer. 1997. Neotropical rainforest mammals: a field guide. 2nd ed. Chicago: University of Chicago Press, 307 pp., 36 pls.

Emmons, L.H., and J.L. Patton. 2005. A new species of Oryzomys (Rodentia: Muridae) from eastern Bolivia. American Museum Novitates 3478: 1-26.

Gardner, A.L. 2008. Mammals of South America. Vol. 1. Marsupials, xenarthrans, bats, and shrews. Chicago: University of Chicago Press.
Gardner, A.L., and J.L. Patton. 1976. Karyotypic variation in oryzomyine rodents (Cricetinae) with comments on chromosomal evolution in the Neotropical cricetine complex. Occasional Papers of the Museum of Zoology Louisiana State University 49: 1-48.

Goldman, E.A. 1918. The rice rats of North America (Genus Oryzomys). North American Fauna 43: 1-100.

Gyldenstolpe, N. 1932. A manual of Neotropical sigmodont rodents. Kungliga Svenska Vetenskapsakademiens Handlingar Tredje Serien 11: $1-164$.

Hall, E.R. 1981. The mammals of North America. 2nd ed. New York: John Wiley, 1181 pp.

Handley, C.O., Jr. 1976. Mammals of the Smithsonian Venezuelan Project. Brigham Young University Science Bulletin Biological Series 20: 1-89.

Hershkovitz, P. 1960. Mammals of northern Colombia, preliminary report no. 8: Arboreal rice rats, a systematic revision of the subgenus Oecomys, genus Oryzomys. Proceedings of the United States National Museum 110: 513-568.

Massoia, E., and A. Fornes. 1965. Oryzomys (Oecomys) Thomas, 1906, Nuevo subgenero de cricetidos para la Republica Argentina (Rodentia). Physis Sección C 25: 319324.

Musser, G.G., and M.D. Carleton. 1993. Family Muridae. In D.E. Wilson and D.M. Reeder (editors), Mammal species of the world: a taxonomic and geographic reference. 2nd ed.: 501-755. Washington, DC: Smithsonian Institution Press, xviii + 1206 pp.

Musser, G.G., and M.D. Carleton. 2005. Superfamily Muroidea. In D.E. Wilson and D.M. Reeder (editors), Mammal species of the world: a taxonomic and geographic reference. 3rd ed. Vol. 2: 894-1531. Baltimore, MD: Johns Hopkins University Press.

Musser, G.G., M.D. Carleton, E.M. Brothers, and A.L. Gardner. 1998. Systematic studies of oryzomyine rodents (Muridae: Sigmodontinae): diagnoses and distributions of species formerly assigned to Oryzomys "capito." Bulletin of the American Museum of Natural History 236: 1-376.

Musser, G.G., and J.L. Patton. 1989. Systematic studies of oryzomyine rodents (Muridae): the identity of Oecomys phelpsi Tate. American Museum Novitates 2961: 1-6.

Myers, P. 1982. Origins and affinities of the mammal fauna of Paraguay. University of Pittsburgh Pymatuning Laboratory of Ecology Special Publication 6: 85-93. 
Osgood, W.H. 1916. Mammals of the Collins-Day South American Expedition. Field Museum of Natural History Publications Zoological Series 10(14): 199-216.

Pardiñas, U.F.J., and P. Ramírez-Llorens. 2005. The genus Oecomys (Rodentia, Sigmodontinae) in Argentina. Mammalia 69: 103-107.

Patton, J.L., M.N.F. da Silva, and J.R. Malcolm. 2000. Mammals of the Rio Juruá and the evolutionary and ecological diversification of Amazonia. Bulletin of the American Museum of Natural History 244: 1-306.

Paynter, R.A., Jr. 1982. Ornithological gazetteer of Venezuela. Cambridge, MA: Harvard University Museum of Comparative Zoology, iv $+245 \mathrm{pp}$.

Paynter, R.A., Jr. 1992. Ornithological gazetteer of Bolivia. 2nd ed. Cambridge, MA: Harvard University Museum of Comparative Zoology, $\mathrm{xi}+185 \mathrm{pp}$.

Paynter, R.A., Jr. 1997. Ornithological gazetteer of Colombia. 2nd ed. Cambridge, MA: Harvard University Museum of Comparative Zoology, ix +537 pp.

Paynter, R.A., Jr., and M.A. Traylor, Jr. 1991. Ornithological gazetteer of Brazil. Cambridge, MA: Harvard University Museum of Comparative Zoology, vii +788 pp.

Pelzeln, A. von. 1871. Zur Ornithologie Brasiliens, Resultate von Johann Natterer Reisen in den Jahren 1817 bis 1835. Wien: A. Pichler's Witwe, $462 \mathrm{pp}$.

Reig, O.A. 1977. A proposed unified nomenclature for the enamelled components of the molar teeth of the Cricetidae (Rodentia). Journal of Zoology (London) 181: 227-241.

Reig, O.A. 1984. Distribução geográfica e história evolutiva dos roedores muroideos sulamericanos (Cricetidae: Sigmodontinae). Revista Brasileira de Genetica 7: 333-365.

Smith, M.F., and J.L. Patton. 1999. Phylogenetic relationships and the radiation of sigmodontine rodents in South America: evidence from cytochrome $b$. Journal of Mammalian Evolution 6: 89-128.

Steppan, S.J. 1995. Revision of the Tribe Phyllotini (Rodentia: Sigmodontinae), with a phylogenetic hypothesis for the Sigmodontinae. Fieldiana Zoology New Series 80: 1-112.

Stotz, D.F., J.W. Fitzpatrick, T.A. Parker, and D.K. Moscovits. 1996. Neotropical birds: ecology and conservation. Chicago: University of Chicago Press, $\mathrm{xx}+478 \mathrm{pp}$.

Tate, G.H.H. 1932. The taxonomic history of the South and Central American cricetid rodents of the genus Oryzomys. Part 1: Subgenus Oryzomys. American Museum Novitates 579: $1-18$.
Thomas, O. 1899. Descriptions of new rodents from the Orinoco and Ecuador. Annals and Magazine of Natural History (7) 4: 378-383.

Thomas, O. 1904. On the mammals collected by Mr. A. Robert at Chapada, Matto Grosso (Percy Sladen Expedition to Central Brazil). Proceedings of the Zoological Society of London (1903) 2: 232-244.

Thomas, O. 1906a. Notes on South American rodents. II. On the allocation of certain species hitherto referred respectively to Oryzomys, Thomasomys, and Rhipidomys. Annals and Magazine of Natural History (7) 18: 442-445.

Thomas, O. 1906b. Notes on South American rodents. III. A new Oecomys and two new species of Holochilus. Annals and Magazine of Natural History (7) 18: 445-448.

Thomas, O. 1910. Mammals from the River Supinaam, Demerara, presented by Mr. F. V. McConnell to the British Museum. Annals and Magazine of Natural History (8) 6: 184-189.

Tomes, R.F. 1860. Notes on a second collection of Mammalia made by Mr. Fraser in the Republic of Ecuador. Proceedings of the Zoological Society of London 1860: 211-221.

United States Board on Geographic Names. 1992. Gazetteer of Paraguay. 2nd ed. Washington, DC: Defense Mapping Agency.

Voss, R.S. 1988. Systematics and ecology of ichthyomyine rodents (Muroidea): patterns of morphological evolution in a small adaptive radiation. Bulletin of the American Museum of Natural History 188(2): 259-493.

Voss, R.S. 1993. A revision of the Brazilian muroid rodent genus Delomys with remarks on "thomasomyine" characters. American Museum Novitates 3073: 1-44.

Voss, R.S., and M.D. Carleton. 1993. A new genus for Hesperomys molitor Winge and Holochilus magnus Hershkovitz (Mammalia, Muridae) with an analysis of its phylogenetic relationships. American Museum Novitates 3085: 1-39.

Voss, R.S., and L.H. Emmons. 1996. Mammalian diversity in Neotropical lowland rainforests: a preliminary assessment. Bulletin of the American Museum of Natural History 230: $1-115$.

Voss, R.S., D.P. Lunde, and S.A. Jansa. 2005. On the contents of Gracilinanus Gardner and Creighton, 1989, with the description of a previously unrecognized clade of small didelphid marsupials. American Museum Novitates 3482: 1-34.

Voss, R.S., D.P. Lunde, and N.B. Simmons. 2001. Mammals of Paracou, French Guiana: a neotropical lowland rainforest fauna. Part 2: Nonvolant species. Bulletin of the American Museum of Natural History 263: 1-236. 
Wagner, J.A. 1845. Diagnosen einiger neuen Arten von Nagern und Handflüglern. Archiv für Naturgeschichte 11(1): 145-149.

Wagner, J.A. 1848. Beiträge zur Kenntniss der Säugthiere Amerika's. Abhandlungen der Mathematisch-Physikalischen Classe der Königlich Bayerischen, Akademie der Wissenschaften (München) 5: 269-332.

Wahlert, J.H. 1985. Cranial foramina of rodents. In W.P. Luckett and J.-L. Hartenberger (editors), Evolutionary relationships among rodents: a multidisciplinary analysis: 311-332. New York: Plenum Press.

Weksler, M. 2003. Phylogeny of Neotropical oryzomyine rodents (Muridae: Sigmodontinae) based on the nuclear IRBP exon. Molecular Phylogenetics and Evolution 29: 331-349.

Weksler, M. 2006. Phylogenetic relationships of oryzomine rodents (Muroidea: Sigmodontinae): separate and combined analyses of morphological and molecular data. Bulletin of the American Museum of Natural History 296: 1-149.

\section{APPENDIX 1}

\section{Gazetteer of Mapped Localities}

Cartographic sources included original collector's coordinates as obtained from specimen tags, faunal publications (Anderson, 1997; Handley, 1976), the MCZ ornithological gazetteers on Bolivia, Brazil, Colombia, and Venezuela (Paynter, 1982, 1992, 1997; Paynter and Traylor, 1991), a preliminary gazetteer based on AMNH South American expeditions (AMNH Archives), and the gazetteer from Volume 1 on South American mammals (SAM; Gardner, 2008).

\section{Bolivia}

\author{
Beni, Bahía de los Casara \\ Beni, Baures \\ Beni, Boca del Río Ibare \\ Beni, Busurucucú \\ Beni, El Consuelo \\ Beni, Lúcuma \\ Beni, Magdalena \\ Beni, Puerto Salinas \\ Beni, Río Ibare, 26 km from mouth \\ Beni, Río Iténez, 4 km above Costa Marques \\ Beni, Río Iténez, bank opposite Costa Marques \\ Beni, Río Mamoré \\ Beni, Río Tijamuchi \\ Beni, San Joaquín \\ Beni, Yacuma, 35 km N \\ Beni, Yuatre \\ Chuquisaca, Chuhuayacu, 2 km E \\ Chuquisaca, Río Limón \\ Chuquisaca, Ticucha \\ Chuquisaca, Tihumayo \\ Chuquisaca, Tola Orka \\ Cochabamba, Mission Mosetenes \\ Cochabamba, Río Chapare, mouth of \\ Cochabamba, Río Moile Ichilo \\ Cochabamba, Todos Santos \\ La Paz, Puerto Linares \\ Santa Cruz, El Refugio \\ Santa Cruz, El Refugio, 3 km NE \\ Santa Cruz, Ayacucho \\ Santa Cruz, Basilio \\ Santa Cruz, Buena Vista \\ Santa Cruz, Camiri \\ Santa Cruz, Estación Pailón, 3. 5 km W
}

$13^{\circ} 13^{\prime} \mathrm{S}, 62^{\circ} 21^{\prime} \mathrm{W}$ (Anderson, 1997)

$13^{\circ} 35^{\prime} \mathrm{S}, 63^{\circ} 35^{\prime} \mathrm{W}$ (Anderson, 1997)

$14^{\circ} 37^{\prime} \mathrm{S}, 64^{\circ} 57^{\prime} \mathrm{W}$ (Paynter, 1992)

$14^{\circ} 39^{\prime} \mathrm{S}, 66^{\circ} 17^{\prime} \mathrm{W}$ (Anderson, 1997)

$14^{\circ} 20^{\prime} \mathrm{S}, 67^{\circ} 15^{\prime} \mathrm{W}$ SAM

$13^{\circ} 29^{\prime} \mathrm{S}, 64^{\circ} 15^{\prime} \mathrm{W}$ (Paynter, 1992)

$13^{\circ} 20^{\prime} \mathrm{S}, 6^{\circ} 08^{\prime} \mathrm{W}$ (Anderson, 1997)

$14^{\circ} 20^{\prime} \mathrm{S}, 67^{\circ} 33^{\prime} \mathrm{W}$ (Paynter, 1992)

$14^{\circ} 47^{\prime} \mathrm{S}, 64^{\circ} 51^{\prime} \mathrm{W}$ (Anderson, 1997)

$12^{\circ} 29^{\prime} \mathrm{S}, 64^{\circ} 15^{\prime} \mathrm{W}$ (Anderson, 1997)

$12^{\circ} 29^{\prime} \mathrm{S}, 64^{\circ} 17^{\prime} \mathrm{W}$ (Anderson, 1997)

$12^{\circ} 26^{\prime} \mathrm{S}, 65^{\circ} 11^{\prime} \mathrm{W}$ SAM

$14^{\circ} 56^{\prime} \mathrm{S}, 65^{\circ} 09^{\prime} \mathrm{W}$ SAM

$13^{\circ} 04^{\prime} \mathrm{S}, 64^{\circ} 49^{\prime} \mathrm{W}$ (Paynter, 1992)

$14^{\circ} 52^{\prime} \mathrm{S}, 67^{\circ} 07^{\prime} \mathrm{W}$ Collector

$13^{\circ} 17^{\prime} \mathrm{S}, 64^{\circ} 48^{\prime} \mathrm{W}$ (Anderson, 1997)

$19^{\circ} 43^{\prime} \mathrm{S}, 63^{\circ} 51^{\prime} \mathrm{W}$ Collector

$19^{\circ} 33^{\prime} \mathrm{S}, 64^{\circ} 08^{\prime} \mathrm{W}$ Collector

$20^{\circ} 28^{\prime} \mathrm{S}, 64^{\circ} 04^{\prime} \mathrm{W}$ (Anderson, 1997)

$19^{\circ} 34^{\prime} \mathrm{S}, 6^{\circ} 08^{\prime} \mathrm{W}$ (Anderson, 1997)

$19^{\circ} 27^{\prime} \mathrm{S}, 6^{\circ} 07^{\prime} \mathrm{W}$ (Anderson, 1997)

$16^{\circ} 40^{\prime} \mathrm{S}, 6^{\circ} 03^{\prime} \mathrm{W}$ (Anderson, 1997)

$15^{\circ} 58^{\prime} \mathrm{S}, 64^{\circ} 42^{\prime} \mathrm{W}$ (Paynter, 1992)

$15^{\circ} 57^{\prime} \mathrm{S}, 64^{\circ} 42^{\prime} \mathrm{W}$ (Paynter, 1992)

$16^{\circ} 48^{\prime} \mathrm{S}, 65^{\circ} 08^{\prime} \mathrm{W}$ (Paynter, 1992)

$15^{\circ} 30^{\prime} \mathrm{S}, 67^{\circ} 30^{\prime} \mathrm{W}$ (Paynter, 1992)

$14^{\circ} 46^{\prime} \mathrm{S}, 61^{\circ} 02^{\prime} \mathrm{W}$ Collector

$14^{\circ} 44.58^{\prime} \mathrm{S}, 61^{\circ} 01.33^{\prime} \mathrm{W}$ Collector

$17^{\circ} 51^{\prime} \mathrm{S}, 63^{\circ} 20^{\prime} \mathrm{W}$ (Anderson, 1997)

$18^{\circ} 08^{\prime} \mathrm{S}, 63^{\circ} 19^{\prime} \mathrm{W}$ (Paynter, 1992)

$17^{\circ} 27^{\prime} \mathrm{S}, 63^{\circ} 40^{\prime} \mathrm{W}$ (Paynter, 1992)

$20^{\circ} 06^{\prime} \mathrm{S}, 63^{\circ} 32^{\prime} \mathrm{W}$ (Paynter, 1992)

$17^{\circ} 39^{\prime} \mathrm{S}, 62^{\circ} 45^{\prime} \mathrm{W}$ Collector 
Santa Cruz, Ingeniero, 7 km E, 3 km N

Santa Cruz, Punta Rieles

Santa Cruz, Río Yapacaní

Santa Cruz, San Rafael de Amboró

Santa Cruz, Santa Ana

Santa Cruz, Santa Cruz de la Sierra

Santa Cruz, Santa Cruz, 15 km S

\section{BRAZIL}

Amazonas, Comunidade Tambor

Amazonas, Ilha das Onças

Amazonas, Lago Meduini

Amazonas, Macaco, left bank Rio Jaú

Amazonas, Macaco, right bank Rio Jaú

Amazonas, mouth of Rio Curicuriari

Amazonas, Rio Uaupes opposite Tahuapunto

Amazonas, Yavanari, right bank Rio Negro

Mato Grosso, Caiçara

Mato Grosso, Descalvados

Mato Grosso do Sul, Fazenda Acurizal

Mato Grosso do Sul, Urucúm de Corumbá

Roraima, Rio Uraicbera

\section{Colombia}

Meta, Los Micos

Vichada, Maipures

\section{PARAguay}

Amambay, Colonia Sargento Duré

Chaco, Cerro León

Chaco, San Alfredo

Misiones, San Ignacio, 40 km S

Paraguari, Piribebuy, 17 km SW

VenezUela

Amazonas, Acanaña

Amazonas, Belén

Amazonas, Boca del Rio Ocamo

Amazonas, Boca Mavaca

Amazonas, Río Orinoco, Caño Derecho

Amazonas, El Merly, Río Casiquiare

Amazonas, Esmeralda

Amazonas, Maipures

Amazonas, Río Casiquiare

Amazonas, Río Casiquiare, 12 mi W Rio Jawasu

Amazonas, San Juan de Manapiare

Amazonas, Tama Tama

Apure, Hato Caribén $18^{\circ} 08^{\prime} \mathrm{S}, 63^{\circ} 12^{\prime} \mathrm{W}$ SAM

$16^{\circ} 35^{\prime} \mathrm{S}, 64^{\circ} 12^{\prime} \mathrm{W}$ (Anderson, 1997)

$17^{\circ} 24^{\prime} \mathrm{S}, 63^{\circ} 46^{\prime} \mathrm{W}$ (Anderson, 1997)

$17^{\circ} 36^{\prime} \mathrm{S}, 63^{\circ} 36^{\prime} \mathrm{W}$ Collector

$16^{\circ} 37^{\prime} \mathrm{S}, 60^{\circ} 43^{\prime} \mathrm{W}$ (Paynter, 1992)

$17^{\circ} 48^{\prime} \mathrm{S}, 63^{\circ} 10^{\prime} \mathrm{W}$ SAM

$17^{\circ} 53^{\prime} \mathrm{S}, 63^{\circ} 07^{\prime} \mathrm{W}$ Collector

$02^{\circ} 14^{\prime} \mathrm{S}, 62^{\circ} 26^{\prime} \mathrm{W}$ Collector

$01^{\circ} 49.95^{\prime} \mathrm{S}, 61^{\circ} 22.82^{\prime} \mathrm{W}$ Collector

$01^{\circ} 47.12^{\prime} \mathrm{S}, 61^{\circ} 23.65^{\prime} \mathrm{W}$ Collector

$02^{\circ} 05.02^{\prime} \mathrm{S}, 62^{\circ} 07.35^{\prime} \mathrm{W}$ Collector

$02^{\circ} 04^{\prime} \mathrm{S}, 62^{\circ} 06^{\prime} \mathrm{W}$ Collector

$00^{\circ} 14^{\prime} \mathrm{S}, 66^{\circ} 48^{\prime} \mathrm{W}$ (Paynter and Traylor, 1991)

$00^{\circ} 37^{\prime} \mathrm{N}, 6^{\circ} 06^{\prime} \mathrm{W}$ (Paynter and Traylor, 1991)

$00^{\circ} 31^{\prime} \mathrm{S}, 64^{\circ} 50^{\prime} \mathrm{W}$ (Paynter and Traylor, 1991)

$16^{\circ} 04^{\prime} \mathrm{S}, 57^{\circ} 43^{\prime} \mathrm{W}$ SAM

$16^{\circ} 45^{\prime} \mathrm{S}, 57^{\circ} 42^{\prime} \mathrm{W}$ (Paynter and Traylor, 1991)

$17^{\circ} 51^{\prime} \mathrm{S}, 57^{\circ} 35^{\prime} \mathrm{W}$ SAM

$19^{\circ} 09^{\prime} \mathrm{S}, 57^{\circ} 38^{\prime} \mathrm{W}$ SAM

$03^{\circ} 02^{\prime} \mathrm{N}, 60^{\circ} 30^{\prime} \mathrm{W}$ (Paynter and Traylor, 1991)

$03^{\circ} 17^{\prime} \mathrm{N}, 73^{\circ} 53^{\prime} \mathrm{W}$ (Paynter, 1997)

$05^{\circ} 11^{\prime} \mathrm{N}, 67^{\circ} 51^{\prime} \mathrm{W}$ (Paynter, 1997)

\author{
$22^{\circ} 10^{\prime} \mathrm{S}, 56^{\circ} 27^{\prime} \mathrm{W}$ USBGN \\ $20^{\circ} 23^{\prime} \mathrm{S}, 60^{\circ} 19^{\prime} \mathrm{W}$ SAM \\ $19^{\circ} 58^{\prime} \mathrm{S}, 60^{\circ} 03^{\prime} \mathrm{W}$ \\ $26^{\circ} 52^{\prime} \mathrm{S}, 57^{\circ} 45^{\prime} \mathrm{W}$ (AMNH Archives) \\ $25^{\circ} 29^{\prime} \mathrm{S}, 57^{\circ} 03^{\prime} \mathrm{W}$
}

$03^{\circ} 32^{\prime} \mathrm{N}, 65^{\circ} 48^{\prime} \mathrm{W}$ (Handley, 1976)

$03^{\circ} 39^{\prime} \mathrm{N}, 65^{\circ} 46^{\prime} \mathrm{W}$ (Handley, 1976)

$02^{\circ} 48^{\prime} \mathrm{N}, 65^{\circ} 14^{\prime} \mathrm{W}$ (Paynter, 1982)

$02^{\circ} 30^{\prime} \mathrm{N}, 65^{\circ} 13^{\prime} \mathrm{W}$ SAM

$02^{\circ} 48^{\prime} \mathrm{N}, 65^{\circ} 14^{\prime} \mathrm{W}$ (AMNH Archives)

$03^{\circ} 05^{\prime} \mathrm{N}, 65^{\circ} 55^{\prime} \mathrm{W}$ (Paynter, 1982)

$03^{\circ} 10^{\prime} \mathrm{N}, 65^{\circ} 33^{\prime} \mathrm{W}$ (Paynter, 1982)

$05^{\circ} 10^{\prime} \mathrm{N}, 67^{\circ} 47^{\prime} \mathrm{W}$ (Paynter, 1982)

$02^{\circ} 01^{\prime} \mathrm{N}, 67^{\circ} 07^{\prime} \mathrm{W}$ (Paynter, 1982)

$01^{\circ} 58^{\prime} \mathrm{N}, 66^{\circ} 42^{\prime} \mathrm{W}$ (AMNH Archives)

$05^{\circ} 05^{\prime} \mathrm{N}, 66^{\circ} 05^{\prime} \mathrm{W}$ (Paynter, 1982)

$03^{\circ} 09^{\prime} \mathrm{N}, 65^{\circ} 50^{\prime} \mathrm{W}$ (Paynter, 1982)

$06^{\circ} 33^{\prime} \mathrm{N}, 67^{\circ} 13^{\prime} \mathrm{W}$ (Handley, 1976) 


\section{APPENDIX 2}

REDESCRIPTION OF HESPEROMYS CONCOLOR IN THE Original German (Wagner, 1848: 311-312)

5. Hesperomys concolor Wagn. Die gleichfarbige Scharrmaus.

H. fulvus, subtus abrupte albus, pedibus fuscentibus; cauda nuda longitudine corporis; pilis gastraei unicoloribus.

Hesperomys concolor A. Wagn. im Arch. F. Naturgesch. 1845. S. 147.

Wir hatten diese Art anfänglich für eine Abanderung von Hesperomys Anguya angsehen; nachdem ich sie aber dahier genauer mit letzterer verglichen habe, scheint es mir doch richtiger sie als eigne Art aufzustellen. Sie ist allerdings mit $H$.
Anguya sehr nahe verwandt, aber die Färbung der Oberseite ist bei ihr weit lebhafter, mit mehr Roth beigemischt, dagegen mit weniger Schwarz gesprenkelt. Die Unterseite, welche schön weiss ist, hat lauter einfarbige Haare, dagegen H. Anguya zweifarbige; ferner fehlt die graue Färbung auf den Wangen des letzteren und die Fusse sind mit bräunlichen Haaren besetzt; der nackte, nur mit kurzen Härchen beflogene Schwanz hat eine dunkle Färbung. Die Schnurren sind schwarz und die Ohren wie bei $H$. Anguya behaart.

\begin{tabular}{|c|c|c|}
\hline & H. concolor & H. Anguya \\
\hline Körper & $4^{\prime \prime} 10^{\prime \prime \prime}$ & $5^{\prime \prime} 8^{\prime \prime \prime}$ \\
\hline Schwanz & 49 & 56 \\
\hline Ohren & $\begin{array}{lll}0 & 62 / 2 \text { [sic] }\end{array}$ & 08 \\
\hline Hinterfuss & 10 & 13 \\
\hline
\end{tabular}

Natterer fand diese Art am Flusse Curicuriari im nordwestlichen Brasilien.

Complete lists of all issues of the Novitates and the Bulletin are available at World Wide Web site http://library.amnh.org/pubs. Inquire about ordering printed copies via e-mail from scipubs@amnh.org or via standard mail from: American Museum of Natural History, Library-Scientific Publications, Central Park West at 79th St., New York, NY 10024. TEL: (212) 769-5545. FAX: (212) 769-5009. 